\title{
THE
}

\section{Do Lower Top Marginal Tax Rates Slow the Income Growth of Workers?}

Liam C. Malloy

University of Rhode Island, Imalloy@uri.edu

Follow this and additional works at: https://digitalcommons.uri.edu/ecn_facpubs

The University of Rhode Island Faculty have made this article openly available.

Please let us know how Open Access to this research benefits you.

This is a pre-publication author manuscript of the final, published article.

Terms of Use

This article is made available under the terms and conditions applicable towards Open Access Policy Articles, as set forth in our Terms of Use.

\section{Citation/Publisher Attribution}

Malloy, L. C. (2016). Do Lower Top Marginal Tax Rates Slow the Income Growth of Workers?. Labour, 30(1), 61-87.

Available at: https://doi.org/10.1111/labr.12073

This Article is brought to you for free and open access by the Economics at DigitalCommons@URI. It has been accepted for inclusion in Economics Faculty Publications by an authorized administrator of DigitalCommons@URI. For more information, please contact digitalcommons@etal.uri.edu. 


\title{
Do Lower Top Marginal Tax Rates Slow the Income
}

\section{Growth of Workers?}

\author{
Liam C. Malloy \\ University of Rhode Island
}

Department of Economics

University of Rhode Island

Kingston, RI 02881

lmalloy@mail.uri.edu

(401)874-4117

August 2015 (First Draft: November 2012)

\begin{abstract}
Top marginal tax rates are positively correlated with the pretax income growth of the bottom $90 \%$ - those who are not subject to the top rates. To explain this correlation, this paper presents and tests a model in which executives can increase firm profitability by: (i) increasing the firm's level of technology and (ii) decreasing labor costs. In the model, higher marginal tax rates may reduce pre-tax inequality by increasing the average income growth of workers. This hypothesis is tested by examining the effect of top marginal tax rates on (unobserved) relative bargaining power between labor and firms and, therefore, on the income growth of workers in the United States. Bargaining power, in both the theoretical and empirical model, is proxied by private-sector unionization and use of offshore labor resulting in higher imports.

Keywords: Income inequality, marginal tax rates, executive behavior, bargaining, unions
\end{abstract}

(JEL Codes: D31, E25, H23) 


\section{Introduction}

While income inequality has been the subject of much recent research, there has been little agreement about why inequality in the United States and many other countries has increased so dramatically from the mid-1970s to the present day. One school of thought has focused on skill-biased technological growth (e.g. Goldin and Katz [2009]), in which demand for highly skilled labor has increased faster than its supply, increasing the return to education and thereby increasing inequality. While this process does seem to explain how the middle of the income distribution has become more spread out, it fails to account for the terrific incomes at the very top of the distribution as documented by Piketty and Saez [2003]. Another school of thought, for example Frank and Cook [2010], attributes the increase to winner-take-all markets in which those with the very highest skills have seen their reach extend globally and have reaped the economic rewards. But as Atkinson and Piketty [2007] have shown, increasing globalization, faced by all developed countries, has not had the same effect on top incomes around the world. In fact, the huge income increases at the top have taken place mainly in English-speaking countries, and not in continental Europe and Asia.

Recent work by Piketty et al. [2014] has shown that income tax policy is relevant to this debate. They show that higher marginal tax rates (MTRs) at the very top are associated with smaller pre-tax top income shares (and larger bottom income shares), both in the Unites States and in an OECD panel. This result is not surprising, and indeed agrees with standard economic theory. But Piketty et al. [2014] also show that neither the traditional labor supply elasticity nor the possibility of tax avoidance can account for much of the correlation. Instead, they find support for a third elasticity in which executives - who make up a significant fraction of those at the top according to Bakija et al. [2010] - have an incentive to increase their bargaining power when facing a lower MTR in order to increase their total compensation. In their main model, executives are able to increase their compensation by reducing the compensation of everybody else in the economy equally. They show in an online appendix that this model carries over to a hierarchical labor model in which executives reduce 
the compensation of those below them, but they say: "The main difficulty with this scenario is that it is difficult to obtain compelling direct evidence that the surge in top incomes did come at the expense of lower earners" (Piketty et al. [2014], p. 268).

This paper attempts to address that issue by focusing on factors that may affect the relative bargaining power of executives and labor in the United States. I propose a simple model in which executives can split their labor between increasing a firm's total factor productivity, increasing the firm's bargaining power over labor, and leisure. Lower MTRs induce them to work more (or at least harder), sacrificing leisure. Depending on how they split the rest of their labor, their efforts may lead to a combination of two outcomes: higher economic growth and higher firm profitability (at least pre-executive pay) on the one hand, and lower income growth for those not at the top on the other ${ }^{1}$. The lower income growth could reflect a decrease in the bargaining power of labor.

I test this model with long-term data in the United States using a full-information maximum likelihood structural equation model (FIML SEM), which allows the main endogenous variables to affect each other. The changes in bargaining power stem mainly from a reduction in labor unionization and firms' increasing reliance on offshore production, resulting in higher levels of imports. These two measures, both of which reduce income growth for workers, are very highly correlated with the MTR, and I show that a significant fraction of the reduction in the real income growth of the bottom $90 \%$ can be explained by the change in the MTRs of the top $0.01 \%$. On the other hand, I find no evidence that lower MTRs for this group result in faster economic growth. Interestingly, the MTRs faced by the top $1 \%$ do seem to be negatively related to per capita growth. Milligan and Smart [2015], in their work estimating tax elasticities in Canada, find similar differences between the top $1 \%$ and top $0.01 \%$, at least at the provincial level. This suggests that instead of flattening the federal tax code by reducing the number of brackets, the United States may want to return to a period

\footnotetext{
${ }^{1}$ This model is completely consistent with the ideas in Kaplan [2012] in which CEOs are (appropriately) paid for performance or the empirical results of Bertrand and Schoar [2003] that show significant effects of CEO performance on firm profitability. In this model, CEOs get paid for increasing profitability, the question here is whether this is done through TFP growth or through zero-sum compensation bargaining.
} 
of more tax brackets at the top with higher MTRs for subgroups within the top 1\%. The political problem, from labor's point of view, is one of collective action as identified by Olson [1965]. As an amorphous group, especially as union membership has declined, labor finds it much more difficult to exert political pressure than do the handful of groups representing the top $0.01 \%$.

\subsection{Background of Top Marginal Tax Rates and Income Shares}

In the United States over the post-WWII period, there has been a strong negative correlation between the top MTR and the pre-tax share of income of the top $1 \%$ and $0.01 \%$. According to data from Piketty and Saez [2003] (updated online), the (non-capital gains) income share of the top $1 \%$ has grown from a low of $7.7 \%$ in 1973 to a pre-recession high of $18.3 \%$ in 2007 . The top $0.01 \%$ has seen even more significant gains, increasing from just under $0.5 \%$ in 1973 to $3.6 \%$ in 2007 . Over the same period the top federal marginal income tax rate fell from $70 \%$ to $35 \%$ (although those in the top $1 \%$ but below the very top faced a $50 \%$ MTR in 1973). According to Piketty and Saez [2003], the 90-99th percentiles have seen their income share fluctuate, varying between a low of $21 \%$ to a high of almost 31\%. From 1974 to 2008 the share of this group increased from $24.2 \%$ to $27.9 \%$.

The income share of the bottom $90 \%$ followed a different trajectory. It was $68.1 \%$ of income in 1973 and fell to less than 55\% in 2007. Between 1950 and 1973, average real income growth for this group was about $2.4 \%$ per year. Between 1974 and 2010 it was barely above zero. During this latter period, average incomes of the top $1 \%$ and $0.01 \%$ grew at an annual rate of over $3 \%$ and over $6 \%$ respectively.

Who are the very rich? The top $1 \%$, and even more the top $0.1 \%$, are not just successful entertainers, athletes, hedge-fund managers, and trust funders. If they were, we wouldn't really expect any relationship between the marginal rate faced by this group and the average incomes of the bottom 90\%. Bakija et al. [2010] show that in 2005 non-finance executives, 
managers, and supervisors made up $31 \%$ of the top $1 \%$ and $42.5 \%$ of the top $0.1 \%^{2}$. These are mostly salaried executives of publicly-traded corporations or executive-owners of closelyheld businesses. In other words, a large percentage of those at the top (especially the very top) are at the head of firms employing workers. They show that, in 2005, the income within these subgroups was even more concentrated than for the relevant percentiles as a whole. Of the approximately $17 \%$ of income that went to the top $1 \%$ and the $7.3 \%$ that went to the top $0.1 \%$, non-financial executives and financial professionals received $53.7 \%$ and $66.3 \%$ respectively. Bakija et al. [2010] unfortunately do not include the breakout for the top $0.01 \%$. If the pattern continued, this group would include an even larger percentage of executives, managers, and financial professionals capturing an even larger share of the pie.

Typically, models that focus on the effects of increasing the top MTR concentrate on two sets of outcomes: the effects on those who earn the top incomes, the effects of after-tax income redistribution, or both. Slemrod [2000] provides a summary of both the relevant questions on how raising the top MTR may affect the rich and the various lines of research. One important question is whether those at the top of the income distribution will work less when MTRs are increased. Moffitt and Wilhelm [2000] use the 1986 Tax Reform Act and Survey of Consumer Finances to look for effects of changes in the MTR on both adjusted gross income and hours worked. Consistent with Feldstein [1995], they find that reported income increases as MTRs decrease. However, they find little effect of changes in MTRs on the number of hours worked, possibly because high-income workers already put in very high hours. In response, Taber [2000] points out that the increase in reported income due to low marginal rates may be attributable to a change in the type of work, rather than the quantity (and may not be due to tax avoidance).

In their survey of tax elasticities, Saez et al. [2012] also point out that while hours worked do not seem to be sensitive to tax rates, taxable income is. They discuss the possibility of externalities in response to changes in tax rates, such as charitable giving and mortgage-

\footnotetext{
${ }^{2}$ Financial professionals, including management, added $13.9 \%$ and $18.0 \%$ respectively.
} 
financed housing purchases. Saez et al. mention the possibility that executives may work to increase their pay when faced with lower MTRs at the expense of shareholders as discussed in Bebchuk and Fried [2004]. They do not mention the possibility that executives may do the same thing with respect to workers' wages.

But what do CEOs actually do? Classical economic theory says that they are hired by shareholders to maximize the firm's long-term profits (see Kaplan [2012] and Bertrand and Schoar [2003] for support of this theory). This relationship has been analyzed as a principalagent problem in which the goals of the CEO may differ from those of shareholders. But less has been said about the mechanisms through which CEOs are meant to increase profits. Gabaix and Landier [2008] propose a model in which executives have different talent levels which interact with firm size to explain the fact that while profit levels explain only a small fraction of CEO pay, firm size explains a lot (Tosi et al. [2000]). A hint of one CEO task comes from both Banning and Chiles [2007] and Gomez and Tzioumis [2011], both of which find that CEOs of non-union firms earn more than CEOs in union firms. Think of a firm as an entity that takes inputs (labor, capital, technology, executive skill) and creates positive economic profits (or rents). It must then distribute those profits among its inputs. How they get distributed will depend on a number of factors, and these will reflect the relative bargaining power of each group. For our purposes, the most relevant issue is the relative bargaining power of labor.

Traditionally, unions significantly increased labor's bargaining power. Bluestone and Bluestone [1992] found that union workers earned 15-20\% more than non-union workers 20 years ago. Recent work (Blanchflower and Bryson [2003], Blanchflower and Bryson [2004], Blackburn [2008], Hirsch [2008]) finds that the wage differential may be a bit lower, but is still at least 10\%. Lemieux [2008] shows that declining union membership in the U.S. is likely one cause of increasing wage inequality.

In the 1970s and 1980s, union-management relations became more contentious. Kochan et al. [1986] believe this was due to increased competitive pressure from lower-cost labor 
abroad and non-union workers in the United States. They note that of the two million jobs lost in manufacturing in the early 1980s, half were union jobs. Bluestone and Bluestone [1992] note that as firms' profit levels began to decline two decades after WWII, one route managers took was to "aggressively challenge the wage demands of their employees" (p.67). Walton et al. [1994] claim that managers opposed unions not only to increase their own flexibility and the productivity of their workers, but also to reduce pay and benefits, either in absolute terms or relative to their previous growth rates. Some recent research has found that an increased reliance on off-shore production has reduced wages for workers in similar industries (Autor et al. [2013] and Ebenstein et al. [2013]), a finding supported in this paper, although other research (such as Gomez et al. [2013]) finds less of an effect, at least for service sector employees.

The following section presents the model in which executives choose between leisure and work and decide on how to split their time between the two types of work -increasing a firm's total factor productivity and increasing the firm's bargaining power over labor. Section three tests the model's hypotheses with a time series data set for the United States. Section four concludes and offers steps for further research.

\section{Model}

\subsection{Setup}

There are an exogenous number of firms, $n$, in the market, producing a homogenous good. There is also an unproduced good, $M$, serving as the numeraire. Following Lasselle and Svizzero [2005], firms compete in a Cournot oligopoly in the produced good. The total demand curve depends on its price and total disposable income in the economy $(I+M)$ :

$$
Q=D\left(p_{j}, I, M\right)
$$


The two main assumptions are that demand is decreasing in price and increasing in total income:

$$
\begin{aligned}
& \frac{\partial D\left(p_{j}, I, M\right)}{\partial p_{j}}<0 \\
& \frac{\partial D\left(p_{j}, I, M\right)}{\partial I}>0
\end{aligned}
$$

Firms are assumed to be large enough in their market that they possess some market power, but small enough in the total economy that they take income as given (as in Hart [1982]). Each firm's demand curve will depend on total income and the production of the rest of the firms in the market:

$$
q_{j}=D_{j}\left(p_{j}, I, M, Q-q_{j}\right)
$$

Firms produce according to the production function:

$$
y_{j}=A_{j} f\left(L_{j}^{D}, L_{j}^{F}\right)
$$

Where $A_{j}$ is the firm's level of technology, $L^{D}$ is domestic labor and $L^{F}$ is foreign labor. I assume that domestic labor is paid the endogenous wage, $\omega$, and foreign labor is paid the exogenous wage, $\hat{\omega}$, where I assume that $\omega>\hat{\omega}$. The production function, $f(\cdot, \cdot)$ is assumed to be increasing and at least weakly concave in both inputs. The productivity of domestic labor is assumed to be greater than that of foreign labor, $f_{1}(\cdot, \cdot)>f_{2}(\cdot, \cdot)$. In addition, there is assumed to be a (firm-specific) fixed cost of producing overseas of $\Delta_{j}\left(L_{j}^{F}\right)$ (where $\Delta(0)=0)$

For a given market price, $p_{j}$, and with firm production equal to firm demand $\left(y_{j}=q_{j}\right)$, firm profit is then: 


$$
\pi_{j}=p_{j} y_{j}-\omega L_{j}^{D}-\hat{\omega} L_{j}^{F}-\Delta_{j}\left(L_{j}^{F}\right)
$$

If we let a firm's marginal cost be $c_{j}\left(L_{j}^{D}, L_{j}^{F}, A_{j}\right)$, which is a function of how much domestic and offshore labor is used and the firm's level of technology, the profit-maximizing decision becomes a (more or less) straightforward Cournot game. Each firm's quantity and profit are increasing in the level of demand (which is increasing in income) and decreasing in marginal cost. The price is increasing in the level of demand/income and increasing in the marginal cost. Profits, for the firm and in total, are increasing in demand/income and decreasing in marginal cost. Marginal costs, in turn, are decreasing in the firm's level of technology and increasing in the average wage paid to labor, $\bar{\omega}$ :

$$
\begin{aligned}
& \frac{\partial \pi_{j}}{\partial I}>0 \\
& \frac{\partial \pi_{j}}{\partial a_{j}}>0 \\
& \frac{\partial \pi_{j}}{\partial \bar{\omega}}<0
\end{aligned}
$$

There are three distinct types of agents in the model: workers $\left(N_{i}\right)$, shareholders $\left(N_{s}\right)$, and executives $\left(N_{e}\right)$. I assume that workers make up the bulk of the population so that:

$$
N_{i} \gg N_{s}>N_{e} \quad \text { and } \quad N_{i}+N_{s}+N_{e}=1
$$

The focus of this model is the role of the head of the firm, the chief executive officer (CEO). While CEOs can have a number of incentives (minimizing risk, increasing tenure, building reputation, etc.), this paper assumes that the CEO's goal is to maximize utility, which depends on consumption and leisure. The CEO's pay is assumed to be directly related 
to profits. In this model, profits increase with the level of technology $\left(A_{j}\right)$ and decrease with the wage rate paid to workers $(\bar{\omega})$. CEOs can split their time $(e)$ between encouraging the firm to improve the level of technology $\left(e_{A}\right)$ or by decreasing the wage rate $\left(e_{\omega}\right)$ (through bargaining, reducing the power of unions, sending production offshore, etc.), or leisure $(l)$. In return, I make the simplifying assumption that CEOs are paid some fraction, $\gamma$, of the firm's profits ${ }^{3}$.

Executives make up a mass of $N_{e}$ of the population. Total executive income is $I_{e}=$ $\int_{j}\left(\gamma\left(\pi_{j}\right) d e\right.$ and disposable income is $I_{e}^{D}=\int_{j}\left(1-\tau_{e}\right) \gamma\left(\pi_{j}\right) d e$.

The remainder of profits, $(1-\gamma) \pi_{j}$, are distributed to shareholders who are assumed to be distinct from the workers of the firms. Shareholders, with a mass of $N_{s}$, receive a share of the firm's profits as their income. Total income for shareholders is then $I_{s}=\int_{j}(1-\gamma) \pi_{j} d s$ and disposable income is $I_{s}^{D}=\int_{j}\left(1-\tau_{s}\right)(1-\gamma) \pi_{j} d s$.

Because firms can choose to produce domestically and/or offshore, imports from firm $j$ will equal:

$$
I M_{j}=p_{j} A_{j} f\left(\cdot, L_{j}^{F}\right)
$$

Government has to fund some exogenous level of spending $\bar{G}$ with tax revenue from executives, shareholders, and workers. The government's budget constraint is then:

$$
\bar{G}=\tau_{\omega} \int_{i} \omega_{i} d i+\tau_{s} \int_{j}(1-\gamma) \pi_{j} d s+\tau_{e} \int_{j} g\left(\pi_{j}\right) d e
$$

The average tax rate in the economy is then:

$$
\bar{\tau}=\frac{\bar{G}}{I_{\omega}+I_{s}+I_{e}}=\frac{\tau_{\omega} \int_{i} \omega_{i} d i+\tau_{s} \int_{j}(1-\gamma) \pi_{j} d s+\tau_{e} \int_{j} \gamma\left(\pi_{j}\right) d e}{\int_{i} \omega d i+\int_{j}\left((1-\gamma) \pi_{j}\right) d s+\int_{j} \gamma\left(\pi_{j}\right) d e}
$$

\footnotetext{
${ }^{3}$ This assumes that the principal-agent problem between shareholders and executives has been solved and so their incentives are aligned. As Bebchuk and Fried [2004] note, this may not be the case and there may be an additional bargaining problem to be solved. This assumption, however, allows me to focus more specifically on the executive-worker bargaining problem.
} 
Total demand comes from workers, shareholders, executives and the government and must, in equilibrium, be equal to total output as there is no investment in this economy. However, the output that is produced offshore, with foreign labor, will be classified as imports, so that consumption is:

$$
C=I_{\omega}^{D}+I_{s}^{D}+I_{e}^{D}
$$

Total nominal output is:

$$
Y=Y^{D}+Y^{F}=\int_{j} p_{j} y_{j} d j
$$

Which can be broken into domestic output and imports (production done offshore):

$$
Y=Y^{D}+I M=\int_{j} p_{j} A_{j} f\left(L_{j}^{D}, \cdot\right) d j+\int_{j} p_{j} A_{j} f\left(\cdot, L_{j}^{F}\right) d j=I_{\omega}+I_{s}+I_{e}+I_{\hat{\omega}}=I_{\omega}+\Pi+I_{\hat{\omega}}
$$

And the national accounting identity (setting domestic output equal to domestic demand minus imports) equal to total domestic income:

$$
G D P=Y^{D}=C+\bar{G}-I M=I_{\omega}+I_{s}+I_{e}=G D I
$$

or

$$
\int_{j} p_{j} A_{j} f\left(L_{j}^{D}, \cdot\right) d j=\int_{i} \omega_{i} d i+\int_{j}(1-\gamma) \pi_{j} d s+\int_{j} \gamma\left(\pi_{j}\right) d e-\int_{j} p_{j} A_{j} f\left(\cdot, L_{j}^{F}\right) d j
$$

As described above, workers are not able to split their time and must either work or not. For the sake of simplicity, I assume that workers are homogenous and have a reservation wage equal to $\omega_{R}$. So long as there is demand for their labor and the offered wage is above 
this reservation wage, workers will supply labor to the firms. In order for workers to be hired in equilibrium the realized wage, $\omega_{j}$, must be between the workers' reservation wage and the wage at which firm profits are zero, $\omega_{0}$, which can be above the worker's marginal product when there are positive economic profits. In addition, I assume that the exogenous foreign wage rate, $\hat{\omega}$, is less than the reservation wage:

$$
\hat{\omega}<\omega_{R} \leq \omega_{j}\left(z_{j}\right) \leq A f_{D}\left(L_{j}^{D}, L_{j}^{F}\right)<\omega_{0}
$$

While the wage rate for foreign workers is (assumed) fixed at $\hat{\omega}$, the wage rate for domestic workers depends on the relative bargaining power between workers and executives (as representatives of the firms), $z_{j}$. In a perfectly competitive labor market with full information, workers are paid their marginal product, $A_{j} f_{D}\left(L_{j}^{D}, \cdot\right)$ in this model. However, a worker's marginal product can be difficult, if not impossible, to observe and there are frictional costs associated with finding a new job or new workers. Therefore there will be some surplus created by each worker-firm match (as in Mortensen and Pissarides [1994]), which will be split depending on the relative bargaining power of workers and firms.

I assume that the bargaining power of a firm, $z_{j}$, depends on the firm's ability to move work offshore (which, in turn, depends on the firm's fixed cost of offshoring, $\left.\Delta_{j}\left(L_{j}^{F}\right)\right)$ and the unionization rate in the firm's industry $\left(u n_{j}\right)$. The firm's bargaining power, $z_{j}\left(L_{j}^{F}, u n_{j}\right)$, will be increasing in its use of offshore labor and decreasing in the unionization of its workforce.

How much offshore labor a firm uses will depend on the relative marginal and fixed costs. Assuming that $\hat{\omega}<\omega_{j}$, firms with a lower fixed cost of offshoring and/or greater production (so that the average fixed cost is lower) will use more offshore labor, lowering marginal costs and increasing profits. Executives can spend time and effort on reducing the power of labor to organize and form unions, $e_{z}$, or they can spend time and effort increasing the level of technology in the firm, $e_{A}$.

I assume that the level of unionization, $u n_{j}$, and the firm's cost of offshore production, $\Delta_{j}$, are functions of executive effort in that area, $e_{z}$. That is, executives can spend some of 
their effort reducing unionization levels in their firm or decreasing their cost of producing with less costly foreign labor. This increases the firm's bargaining power, $z_{j}$, and allows the firm to reduce the average wage rate in the firm, reducing marginal costs and increasing profits. This may take the form of direct anti-union activities in the workplace or lobbying state or federal government for more corporate-friendly policies; such lobbying efforts could include supporting right-to-work laws and opposing laws that make unionization easier (see Campolieti et al. [2013] and Lipset et al. [2005] for a U.S.-Canada comparison that shows more direct anti-union action in Canada, likely due to weaker U.S. union power). Effort on the part of executives to increase the firm's bargaining power could include forming partnerships with overseas companies, scouting overseas locations, and any other activity that will make off-shore production easier.

In addition to increasing a firm's bargaining power vis-a-vis labor, an executive can spend effort on increasing the firm's level of technology. This will reduce marginal costs and increase profits. For example, Bloom et al. [2013] find that better management techniques significantly increase productivity in India, with managerial time being one of the constraints on such practices being more widely adopted.

I assume that returns to both types of an executive's labor are increasing in terms of profits and are (at least weakly) concave:

$$
\begin{aligned}
& A^{\prime}\left(e_{A}\right)>0 \\
& A^{\prime \prime}\left(e_{A}\right) \leq 0 \\
& u n^{\prime}\left(e_{z}\right)<0 \\
& u n^{\prime \prime}\left(e_{z}\right) \geq 0
\end{aligned}
$$

The CEO has one unit of time/effort available each period so that the time constraint is given by: 


$$
e_{A}+e_{z}+l=1
$$

and must pay a tax rate on income of $\tau_{e}<1$. CEOs receive utility from both consumption, $c$, and leisure, $l$. Utility is assumed to be increasing and concave in both arguments. Because there is no savings in this model, consumption is simply equal to after-tax income. We can summarize the CEO's problem as:

$$
\max _{e_{A}, e_{\omega}, l, L_{j}^{D}, L_{j}^{F}} u(c, l)
$$

s.t.

$$
\text { (1) } c=\left(1-\tau_{e}\right)\left[\gamma\left(p_{j} A_{j}\left(e_{A}\right) f\left(L_{j}^{D}, L_{j}^{F}\right)-\omega_{j}\left(z_{j}\left(L_{j}^{F}, u n_{j}\left(e_{z}\right)\right)\right) L_{j}^{D}-\hat{\omega} L_{j}^{F}-\Delta\left(L_{j}^{F}\right)\right)\right]
$$

$$
\text { (2) } e_{A}+e_{z}+l=1
$$

where the executive is making the individual decisions about how to split his time and effort and also choosing the firm's profit maximizing levels of domestic and foreign labor. Substituting in for consumption, $c$, and leisure, $l$, and allowing $f_{1}$ and $f_{2}$ to be the partial derivative of the production function with respect to domestic and foreign labor, respectively, and $z_{1}$ and $z_{2}$ to be the first derivative of the bargaining power with respect to foreign labor and unionization levels, respectively, we get the FOCs:

$$
\begin{aligned}
u_{c}(c, l)\left(1-\tau_{e}\right) \gamma p A^{\prime}\left(e_{A}\right) f\left(L^{D}, L^{F}\right)-u_{l}(c, l) & =0 \\
-u_{c}(c, l)\left(1-\tau_{e}\right) \gamma \omega^{\prime}(z, \text { un }) z_{2}\left(L^{F}, \text { un }\right) L^{D}-u_{l}(c, l) & =0 \\
u_{c}(c, l)\left(1-\tau_{e}\right) \gamma p A f_{1}\left(L^{D}, L^{F}\right)-\omega(z) & =0 \\
u_{c}(c, l)\left(1-\tau_{e}\right) \gamma p A f_{2}\left(L^{D}, L^{F}\right)-\omega^{\prime}(z) z_{1}\left(L^{F}, \text { un }\right) L^{D}-\hat{\omega}-\Delta^{\prime}\left(L^{F}\right) & =0
\end{aligned}
$$


where $\Delta^{\prime}\left(L^{F}\right)$ in (12) is either equal to 0 if $L^{F}=0$ or some fixed $\Delta_{j}$ if $L^{F}>0$. Combining (9) and (10) we get:

$$
p A^{\prime}\left(e_{A}\right) f\left(L^{D}, L^{F}\right)=\omega^{\prime}(z, u n) z_{2}\left(L^{F}, u n\right) u n^{\prime}\left(e_{\omega}\right) L^{D}
$$

Equation (13) says that executives will equate the marginal benefit of each type of effort. Equations (11) and (12) equate the marginal product of each type of labor with its marginal revenue. The interesting part of $(12)$ is the additional term $-\omega^{\prime}(z) z_{1}\left(L^{F}\right.$, un $) L^{D}>0$. This shows the additional benefit to the firm of using foreign labor in that it reduces the wage of domestic workers by increasing a firm's bargaining power. Combining (11) and (12), the firm equates the marginal product of each type of labor with its marginal cost:

$$
\frac{f_{1}\left(L^{D}, L^{F}\right)}{f_{2}\left(L^{D}, L^{F}\right)}=\frac{\omega(z)}{\omega^{\prime}(z) z_{1}\left(L^{F}, u n\right) L^{D}+\hat{\omega}+\Delta^{\prime}\left(L^{F}\right)}
$$

Executives will also adjust work and leisure so that the marginal benefit of leisure is equal to the marginal benefit of work (in terms of additional consumption):

$$
\left(1-\tau_{e}\right) \gamma A^{\prime}\left(e_{A}\right) f\left(L^{D}, L^{F}\right)=\frac{u_{l}(c, l)}{u_{c}(c, l)}
$$

Where $u_{l}$ and $u_{c}$ are the marginal utility of leisure and consumption, respectively. Equation (15) shows that as the tax rate faced by executives increases (so that the LHS decreases), executives will increase leisure and decrease consumption (and, therefore, work time/effort).

With this model, we can see the effects of a change in the top MTR not only on the income shares $\left(g(\Pi) / Y^{D}\right.$ for executives, $\omega L^{D} / Y^{D}$ for workers), but also on the growth rates of income for executives and for workers. Through (14) and (15), an increase in the executive's MTR, $\tau_{e}$, induces the executives to provide less effort in both increasing the firms' bargaining position and increasing the firm's technology. This has two effects on a worker's wage. First, it will increase unionization, raising the workers' bargaining power and pushing workers' wages closer to their marginal product. However, because it will reduce the value of $A_{j}$, it 
will also reduce the worker's marginal product, potentially reducing the wage, depending on the strength of the two effects.

The executive tax rate also enters into the firm's profit-maximizing decision in (15) through the effect of $e_{z}$ on bargaining power, and, therefore, the relative marginal costs of domestic vs. foreign labor. A higher MTR reduces effort, $e_{z}$, which in turn increases unionization levels which increases the domestic wage rate and should decrease the amount of domestic labor used.

This leads to the following testable hypotheses:

- H1: An increase in the top MTR should lead to a decrease in each firm's level of technology and, therefore, slower real GDP per capita growth.

- H2: An increase in the top MTR should lead to a decrease in each firm's bargaining power towards labor, leading to lower (pre-executive pay) corporate profits as a share of total income.

- H3a: An increase in the top MTR should lead to an increase in private-sector unionization.

- H3b: An increase in the top MTR should lead to a decrease in reliance on offshore production and, therefore, a decrease in imports as a percent of GDP.

Because wage growth depends positively on the growth in TFP $\left(A_{j}\right)$ and negatively on the firm's bargaining power, $z_{j}$, the effect of an increase of the top MTR (which is hypothesized to reduce both $A_{j}$ and $z_{j}$ ) is ambiguous and must be left to the empirical results. However, we can say:

- H4: If the TFP effect of a change in the top MTR dominates the bargaining effect, then an increase in the top MTR will reduce income growth for workers. If the opposite is true, then an increase in the top MTR will lead to an increase in the income growth of workers. 
There may be general equilibrium effects not captured in the four hypotheses above. Inspecting equation (6), GDP will depend on the overall level of technology and total domestic labor used. The model assumes that a higher tax on executives will lead to a lower level of technological growth (as executives supply less $e_{A}$ ). It will also lead to higher unionization, higher wages, and, therefore, less domestic labor used. On the other hand, domestic demand depends (one-for-one) on domestic income, or GDI ${ }^{4}$. A higher executive tax rate will lead to a pre-tax income redistribution between workers and executives/shareholders as the labor share of income increases and profit decreases. While this redistribution does not affect demand in the model, aggregate demand will be reduced by firms substituting foreign labor for domestic. Cheaper foreign labor, however, will reduce firms' marginal costs, reducing prices but increasing profits ${ }^{5}$. The net effect on real GDP growth, as opposed to H1, is unclear but will be tested in the next section.

\section{Empirical tests}

\subsection{Data}

The data set used in this section is a time series combination of U.S. tax data (Piketty and Saez [2003], updated online, Tax Policy Center, 2010, and Barro and Redlick [2011]), macroeconomic variables (BEA), union data (from Hirsch and Macpherson [2002], updated online) and data on the political composition of the U.S. House of Representatives, Senate, and Presidency. The main explanatory variable is the federal marginal income tax rate faced by those just in the top $1 \%$ and by those just in the top $0.01 \%$, standing in for the executive $\mathrm{MTR}^{6}$. The MTR is calculated by comparing historical tax tables and the nominal threshold

\footnotetext{
${ }^{4}$ As opposed to a Post-Keynesian or Kaleckian model in which the rich have a lower marginal propensity to consume than the workers, in this model the MPC $=1$ for all groups.

${ }^{5}$ This all depends on a Cournot-like market structure. If the market is perfectly competitive, the effects would be different.

${ }^{6}$ This is based on gross income minus government transfers and the nominal threshold to enter into each income group. Each household will face a potentially different marginal rate depending on how deductions affect AGI.
} 
for each top income group. There has been substantial variation in the tax rates faced by these two groups, and as noted above, the concentration of executives appears to increase as we move up the income distribution.

The mechanism in the model through which executives are able to reduce average wage growth depends on the firm's bargaining power which, in turn, depends on unionization levels and use of foreign labor. A lower MTR induces executives to work more (or more intensively), splitting their time between increasing the firm's level of technology (and productivity) and increasing bargaining power. This implies that a decrease in the top MTR should lead to lower private union membership which in turn should lead to lower wage growth for workers. Figure 1 plots the MTR for those just in the top $0.01 \%$ and private union membership from Hirsch and Macpherson [2002]. As you can see, there is an extremely strong correlation $(\rho=0.92)$. The figure also lists some of the major labor and tax events of the time period, showing first an increase in labor's bargaining power with passage of the Wagner Act and increases in the top MTR in 1935 and then a slow erosion of labor's bargaining power. By the 1980s Reagan was able to break the PATCO strike by firing 11,345 air traffic controllers and to cut the top federal MTR to less than $30 \%$.

[Figure 1 about here.]

I use the the average income growth of the bottom $90 \%$ (as opposed to income shares as in Piketty et al. [2014]) as a stand-in for average wage growth of the workers. Similarly, because total executive pay is not available, I will use the share of the top $1 \%$ and $0.01 \%$ as a measure of this income group. In order to focus on long-term trends rather than business cycle effects, I have smoothed the annual data of all growth rates using a Hodrick-Prescott filter $^{7}$. Summary statistics are presented in Table 1. I focus on the growth, both of real GDP per capita and in real average income of the bottom $90 \%$, rather than the level, because of the implications of the model in section 2. In the model, executives face a trade-off every

\footnotetext{
${ }^{7}$ The use of the H-P filter in the variables affected by the business cycle creates autocorrelation in the regression results presented below. I present robust standard errors as one possible correction. Use of bootstrapped standard errors gives very similar results.
} 
period in where to focus their effort, which is, in turn, influenced by their marginal tax rate. This implies that a higher marginal tax rate will be associated with higher growth in income for the bottom $90 \%$ whereas the level will mainly depend on the previous period's level. The use of the H-P filter is meant to identify the contemporaneous effects in the long-run trend of the variables. How well it does this depends on how well it filters out the business cycle effects within the variables ${ }^{8}$.

In addition to the total time period (1930-2008), I also provide a breakdown for what is considered the high growth period (1948-1973) and the more recent period of low growth (1974-2008) (see, for example, Cowen [2011]). What is perhaps striking is that while real average income growth of the bottom $90 \%$ did fall precipitously from $2.43 \%$ per year to $0.07 \%$ per year, average annual growth in real GDP per capita fell by only 12 basis points (from $2.06 \%$ to $1.94 \%$ ). The biggest changes from these two time periods are private-sector unionization (32\% vs $13 \%$ ), imports (4.6\% vs. $11.7 \%$ ) and especially the MTR for the top $0.01 \%(76.75 \%$ vs. $45.67 \%)$.

[Table 1 about here.]

I focus on the top $1 \%$ and the top $0.01 \%$ because of the likelihood that these groups include the greatest number of executives with influence over the greatest number of employees. For example, Piketty and Saez [2003] note that in 2006 the average pay of the top 100 CEOs (including salary, bonus, and exercised stock options) was over $\$ 55$ million, putting them comfortably in the top $0.01 \%$. In addition, the tax data shows that there is a significant difference between the threshold income level of the top $1 \%$ and the top $0.01 \%$.

\footnotetext{
${ }^{8}$ Jones [1995] finds that real GDP per capita growth is stationary. That is, using the Dickey-Fuller test, we can reject the null hypothesis that there is a unit root in the data. He uses this fact to show that there are significant problems with much of the endogenous growth theory literature in which the (increasing, non-stationary) explanatory variables, such as capital investment, levels of human capital, etc., are used to explain a stationary variable which appears to simply fluctuate around a trend line. The analysis here could suffer from the same problems and I address this issue in Appendix A. The takeaway from that analysis is that while the full data for growth (real GDP, bottom 90\%, top 1\%) does appear to be stationary, the Dickey-Fuller test on the H-P trend of these variables fails to reject non-stationarity. Furthermore, there is evidence of cointegration between the endogenous variables in the model and fully-modified OLS regressions of the structural equations finds coefficients of similar magnitude and significance to those presented below in Table 2.
} 
In nominal dollars, and not including capital gains, the 1973 thresholds respectively were $\$ 45,500$ and $\$ 242,900$ (or a ratio of 5.34). By 2007 these thresholds had increased to $\$ 347,600$ and $\$ 6,886,000$ (or a ratio of 19.8 ). There has also been much less variation in the MTR for those just in the top $1 \%$ in the post-WWII period (a range of $28-54 \%$ with a standard deviation of 7.2 ) as opposed to the top $0.01 \%$ (ranging from $28-89 \%$ with a standard deviation of 20.1).

The small size of the top $0.01 \%$, about 15,000 households, also implies that this group is more likely to be able to overcome the collective action problem first noted by Olson [1965]. Indeed, given that this group has control over the most financial resources, it would require only a small minority involved in lobbying the political system to have a potentially large effect. The bottom $90 \%$, on the other hand, has a much harder row to hoe to overcome the collective action problem. In the earlier decades of this sample, unions were able to help solve this collective action problem and exert significant political pressure. Union decline in recent decades, however, has left labor with very little voice in the political process. It is not surprising that the elite tend to have their interests better represented than the median voter (Bartels [2009]).

One area which the model is not able to control for is the treatment of corporate vs. personal income. There have been a number of changes to the tax code in how business income is treated and taxed. However, as Piketty and Saez [2003] have shown, the main increase in income for the top $0.01 \%$ has been from wage and salary income and from business income, which has increasingly come from S-corporations after the 1981 and 1986 tax reform (Saez et al. [2012]) and which is taxed at personal income rates. This likely makes the personal marginal tax rate faced by those at the top of the income distribution the most relevant one for executives, and I use it to test this model. 


\subsection{Structural Equation Model Estimation}

While the model offers a straightforward explanation of how the MTRs faced by executives influence wage and productivity growth, in reality the picture must be much more muddied. While the top MTRs may affect growth in per capita real GDP, real GDP growth will certainly influence the growth rate in the average income of the bottom $90 \%$. Similarly, if executives work to reduce the influence of unions, unions will certainly work to reduce the influence of executives, perhaps by lobbying for higher top MTRs. In addition, increased purchasing power by the bottom $90 \%$ could lead firms to produce more, increasing growth in per capita real GDP and corporate profits. On the other hand, a larger presence of private unions in the economy may reduce economic growth by making firms less flexible. This implies that there is a positive feedback mechanism in the model in which executives are able to increase their bargaining power which then leads to lower labor power, lower marginal tax rates, and more executive bargaining power. Of course, the feedback loop appeared to be working in the opposite direction earlier in the sample period.

In order to control for this endogeneity, I use a full-information maximum likelihood structural equation model. This allows a measure of direct effects, such as the effect of top MTRs on unionization and imports, but also allows for indirect effects. For example, while I do not include the top MTRs in the structural equation for the growth rate of the average income for the bottom $90 \%$ (eqn (i) below) they are included as structural variables in the equations determining unionization rates and imports. Because these variables enter into the growth of average income for the bottom $90 \%$, we can see the indirect effect the top tax rates have on worker income. The direct and indirect effects add up to the total effect and all three are reported below.

The eight structural equations in the model are:

$$
g_{\omega t}=\alpha_{k}+F_{k}\left(g_{y t}, \text { union }_{t}, \text { imp }_{t}, \omega_{t} L_{t} / Y_{t}, \Pi_{t} / Y_{t}\right)+G_{k}\left(\bar{y}_{t}, G D_{t}, W W 2_{t}\right)
$$




$$
\begin{aligned}
g_{y t} & =\alpha_{k}+F_{k}\left(\tau_{t}^{1}, \tau_{t}^{0.01}, \text { union }_{t}\right)+G_{k}\left(\bar{\tau}_{t}, \overline{m t}_{t}, \bar{y}_{t}, G D_{t}, W W 2_{t}\right) \\
\text { union }_{t} & =\alpha_{k}+F_{k}\left(\tau_{t}^{1}, \tau_{t}^{0.01}, \text { imp }_{t}\right)+G_{k}\left(G D_{t}, W W 2_{t}\right) \\
\text { imp }_{t} & =\alpha_{k}+F_{k}\left(\tau_{t}^{1}, \tau_{t}^{0.01}, \text { union }_{t}\right)+G_{k}\left(\exp _{t}, G D_{t}, W W 2_{t}\right) \\
\Pi_{t} / Y_{t} & =\alpha_{k}+F_{k}\left(g_{y t}, \tau_{t}^{1}, \tau_{t}^{0.01}, \text { imp }_{t}, \text { union }_{t}\right)+G_{k}\left(\exp _{t}, G D_{t}, W W 2_{t}\right) \\
\omega_{t} L_{t} / Y_{t} & =\alpha_{k}+F_{k}\left(g_{y t}, \tau_{t}^{1}, \tau_{t}^{0.01}, \text { imp }_{t}, \text { union }_{t}\right)+G_{k}\left(\exp _{t}, G D_{t}, W W 2_{t}\right) \\
\tau_{t}^{1} & =\alpha_{k}+F_{k}\left(\tau_{t}^{0.01}, \text { union }_{t}\right)+G_{k}\left(\bar{\tau}_{t}, \overline{m t r}_{t}, G D_{t}, W W 2_{t}, H R_{t}, \text { Sen }_{t}, \text { Pres }_{t}\right) \\
\tau_{t}^{0.01} & =\alpha_{k}+F_{k}\left(\tau_{t}^{1}, \text { union }_{t}\right)+G_{k}\left(\bar{\tau}_{t}, \overline{m t r}_{t}, G D_{t}, W W 2_{t}, H R_{t}, \text { Sen }_{t}, \text { Pres }_{t}\right)
\end{aligned}
$$

The constant, $\alpha_{k}$, is allowed to vary by equation $k$, and the endogenous variables in the model are (i) the average income growth of the bottom $90 \%, g_{\omega_{t}}$, (ii) real GDP growth per capita, $g_{y t}$, (iii) private union membership as a percentage of private employees, union $t$, (iv) imports as a percentage of GDP, $i m p_{t},(\mathrm{v})$ corporate profits as a percentage of GDP, $\Pi_{t} / Y_{t}$, (vi) the wage and salary share of GDP, $\omega_{t} L_{t} / Y_{t}$, (vii) the MTR for those just in the top $1 \%$, $\tau_{t}^{1}$ and (viii) the MTR for those just in the top $0.01 \%, \tau_{t}^{0.01}$. The exogenous variables in the model include dummy variables for the Great Depression (1930-1940), GD , and World War II (1941-1945), $W W 2_{t}$, the overall average MTR, $m \bar{t} r_{t}$ from Barro and Redlick [2011], total federal taxes as a percent of GDP, $\bar{\tau}_{t}$, exports as a percentage of GDP, $\exp _{t}$, and three political variables: the percent of House, $H R_{t}$, and Senate, $S e n_{t}$, seats held by Democrats and a dummy variable if the president is a Democrat, Pres $s_{t}$. The eight $k$ equations are broken up into the effect of endogenous variables, $F_{k}(\cdot)$, and the effect of variables assumed to be exogenous, $G_{k}(\cdot)^{9}$. The relationship between the endogenous variables is summarized in the stylized path diagram in Figure 2.

\footnotetext{
${ }^{9}$ While the dummy time period variables might not be controversial choices for exogeneity, the others may require more explanation. I assume that average federal taxes and average income are not affected by the relative bargaining power between labor and executives, but only the relative weight faced by each group. That is, given an exogenous total tax revenue requirement, $\bar{G}$ in the model, how the various groups pay is what is endogenous to the model. Exports are assumed to vary due to international macroeconomic and political causes outside the model, and the determination of the political variables is outside the scope of this model and are also assumed to be exogenous.
} 
[Figure 2 about here.]

Table 2 provides regression results for the SEM model above. Each of the eight columns represents one of the structural equations and provides coefficient estimates for the direct, indirect, and total effects of each variable. A value of "No path" states that there is no path in the model for that variable to affect that dependent variable ${ }^{10}$. Robust standard errors are provided in parentheses with one, two, and three asterisks representing statistical significance at the $10 \%, 5 \%$, and $1 \%$ level.

[Table 2 about here.]

The first hypothesis, $H 1$, in section 2 is that higher marginal top tax rates will reduce economic growth as those at the top reduce their effort. Column (ii) provides mixed support for this hypothesis. There does seem to be strong evidence that higher MTRs for the top $1 \%$ do have negative effects on growth both directly and indirectly. The total effect implies that a 1 percentage point increase in the top MTR reduces growth in real GDP per capita by 0.163 percentage points. On the other hand, the direct effect of the MTR on the top $0.01 \%$ is positive, as is the total effect, although only significant at the $10 \%$ level. Recall that the percent of executives in the top percentiles increases as we move up the income ladder. It could be that there is a more traditional labor supply responses to MTRs among the top 1\% than there is among the top $0.01 \%$. The difference between the effects of the two tax rates will be a recurring theme in these results.

The second hypothesis, H2, is that higher top MTRs should lead to lower corporate profits as executives expend less effort in bargaining and labor costs increase. From column (v), higher MTRs for the top $1 \%$ do have a negative effect on corporate profits, but once again, the effect is the opposite for the top MTRs of the top $0.01 \%$. One possibility is that these corporate profits are, by necessity, measured post executive pay. If top MTRs reduce executive pay, as was found by Piketty et al. [2014], then it would make sense for higher

\footnotetext{
${ }^{10} 3 \mathrm{SLS}$ results are similar in sign to the direct effects reported here although coefficients tend to be larger in absolute value and more likely to be significant.
} 
MTRs for the top $0.01 \%$ (those best paid executives) to increase total corporate profits by reducing executive pay.

The relative bargaining power of the firm is captured by the next two hypotheses, H3a and $H 3 b$, which state that higher top MTRs should increase (private sector) unionization and decrease the use of offshore production (and, therefore, imports). Column (iii) shows that the direct effect on unionization of the top 0.01\% MTR supports this hypothesis, but the coefficient on the MTR for the top $1 \%$ has a negative sign. A one percentage point increase in the MTR for the top $0.01 \%$ has a direct increase of 0.216 percentage points on private sector unionization. And while the direct effect of private sector unionization on income growth for the bottom $90 \%$ is not statistically significant, the indirect effect is quite significant, mainly working through the increase in imports. So while column (iv) shows that the effects of the top MTRs on imports is fairly ambiguous and, in general, not statistically significant, there is a significantly negative direct effect of imports on the income growth for workers, and an increase in imports leads to a large and significant decrease in unionization (and an increase in profits). This leads to a significantly positive indirect (and total) effect of unionization levels on worker income growth.

There is no direct path for the top MTRs to affect the growth in average income of the bottom $90 \%$, but we see that the indirect effects are both significant, although of opposite sign. Given the effects of the top MTRs on growth, this is what was expected from our fourth hypothesis, which stated that if higher top MTRs decreased real GDP growth, then it was possible they would decrease growth of average incomes for the bottom $90 \%$ (as is the case for the MTR for the top 1\%). On the other hand, if increases in the top MTR did not decrease economic growth, as is the case for the top $0.01 \%$, then higher top MTRs were likely to increase growth for the bottom $90 \%$. Column (i) shows that a one percentage point increase in the MTR of the top $0.01 \%$ leads to an increase in growth for the bottom $90 \%$ of 0.084 percentage points while a one percentage point increase in the MTR for the top $1 \%$ decreases the growth rate for the bottom $90 \%$ by 0.301 percentage points. 
While these results do not show causality, the correlations are in line with the theory presented in section 2. The size of the estimated coefficients implies that the change in the relative bargaining power between labor and firms as shown by the drop in the average MTR of the top $0.01 \%$ from the $1948-1973$ period to the $1974-2008$ period has the potential to explain most of the shrinkage in income growth for the bottom $90 \%$. These effects seem to be mainly coming from the effect of the top MTRs on union membership (iii), real GDP growth (ii), and imports (iv). Higher MTRs for the top $0.01 \%$ increase private unionization, which in turn increases growth for the bottom 90\% (mainly through lower import levels). The MTR for the top $1 \%$ has the opposite effect on unionization. The effects on imports is a little less clear, but higher top MTRs seem to decrease imports (although not significantly), while imports in turn reduce average income growth for the bottom $90 \%$. Again, the effect for the MTR of the top $1 \%$ is the opposite.

Finally, columns (vii) and (viii) show that higher private sector unionization does lead to higher top MTRs, providing some evidence for the struggle over bargaining power and the potential positive feedback loop over which income group will end up paying the country's tax bill. The model also provides some reason to be wary of increasingly freer trade. In support of the model, imports do increase corporate profits by reducing labor costs. However, in the model, and in the econometric results, increases in trade reduce the bargaining power of workers and reduce the growth rate in their average incomes, in the share of wages and salaries, and, at least in these results, in total growth in real GDP per capita. This is consistent with findings from Autor et al. [2013] and Ebenstein et al. [2013], but it would be interesting to divide up trade between countries of similar labor costs, in which traditional comparative advantage arguments may hold, and trade between countries with disparate levels of development in which the effects of this type of model may be dominant. 


\section{Conclusion}

The main contribution of this paper is to show how top MTRs may affect the pre-tax distribution of income, not only by reducing the income of those at the very top (as would be suggested by standard economic theory) but also by increasing the growth of income for the bottom 90\%. The model presented here suggests that executives will work more (or more intensively) to increase bargaining power of the firm and decrease their labor costs when they face lower MTRs, increasing their income and decreasing that of their workers. At the same time, they may work harder to increase firm-level productivity so that lower top MTRs will yield to faster growth. Overall, the model suggests that higher top MTRs on the top $1 \%$ can hurt economic growth (which can then hurt workers), while increasing the top MTR on the top $0.01 \%$, a group which includes the highest paid CEOs in the largest companies, has only positive effects for economic growth in total and for the bottom $90 \%$. The model implies that there can be a positive feedback loop in which one group finds it easier to increase its bargaining power at the expense of the other group as it increases its share of the economic pie.

Taken all together, the results in section 3 imply that while there is support for the assumption that top $0.01 \%$ executives have an effect on the firm's wage bill and will work harder to reduce it when they face a lower MTR, especially by reducing private sector unionization, they have little effect on technological growth (although there is a negative effect on growth from the top tax rate for the top 1\%). On a macroeconomic level, therefore, while the pre-tax distribution of income seems to have changed significantly over time due to changing top MTRs, there is no negative effect on growth from (much) higher tax rates for the very richest. In fact, the data show a positive relationship between the top MTR and overall GDP growth. This implies that there may be an aggregate demand effect of changing the top MTR in which higher wages for the bottom $90 \%$ boost overall demand leading to an increase in supply, higher growth rates, and higher corporate profits.

The full-information maximum likelihood structural equation model results presented 
above suggest that higher MTRs on the top $0.01 \%$ work indirectly on the average income growth of the bottom $90 \%$. First, lower top MTRs are associated with lower levels of privatesector unionization. This, in turn, reduces the income growth of the bottom $90 \%$. The effect of lower top MTRs on import levels is somewhat ambiguous, but higher import levels do lead to lower levels of unionization and higher corporate profits, which in turn leads to lower income growth for the bottom $90 \%$.

The effects of the MTRs for the top $1 \%$ are almost completely opposite than those of the top $0.01 \%$. This implies that contrary to recent practice (at least since the 1980s) of flattening the federal income tax by reducing the number of brackets, it is possible that we would want more tax brackets at the very top, keeping the rate relatively low for those just in the top $1 \%$ and then increasing it sharply for those in the top $0.1 \%$ and $0.01 \%$. This was the case for most of the years in the time series used here. The difference between the top 0.01\% MTR and the top 1\% MTR averaged 33.2 percentage points between 1930 until 1981, but only 2.4 percentage points from 1982 to 2008 .

This is only one time series in one country. It's certainly possible that the driving force was increased global competition from higher exogenous trade levels, which decreased the power of more expensive union labor and decreased income growth except for those at the top. This would require either a coincidental decrease in top MTRs during the same period or perhaps a misguided policy of reducing tax rates in order to provide incentives for executives to spur economic growth. The historical evidence, however, does provide some support for the positive feedback loop in the model in that executives at the top of the income distribution pushed to decrease union power after WWII with the passage of the Taft-Hartley Act and then the Kennedy-era tax cuts. Union power was further reduced throughout the 1970s and 1980s (e.g. Reagan and the PATCO strike) as executives increased their bargaining power further. An interesting next step would be a cross-country analysis over as long a period as possible looking at the effects of top MTRs on private sector unionization, trade (with developed and developing countries), and the overall effect on economic growth and growth 
of the bottom $90 \%$.

We should bear in mind that a number of developed countries, also competing in the same globalized market, have not seen such large increases in the pre-tax income share of those at the top. As Piketty et al. [2014] show, countries such as Germany, France, Sweden, Spain, and Denmark have not seen the same increase in inequality over the last 45-50 years as the United States (and United Kingdom). In addition, a number of countries have changed their top MTRs significantly over this period while a number of others have kept top rates relatively high. They show that there is a strong correlation between changes in the top MTR and the top $1 \%$ income share (and CEO compensation). Expanding their results to focus on the average real income growth of the bottom $90 \%$, and its relationship to unionization and trade, would provide more evidence for or against the hypothesis that executives work harder to reduce labor costs when top MTRs are lower.

\section{References}

Atkinson, Anthony Barnes and Thomas Piketty (2007) Top incomes over the twentieth century: a contrast between continental European and English-speaking countries: Oxford university press.

Autor, H, David, David Dorn, and Gordon H Hanson (2013) "The China Syndrome: Local Labor Market Effects of Import Competition in the United States," The American Economic Review, Vol. 103, No. 6, pp. 2121-2168.

Bakija, Jon, Adam Cole, and Bradley T. Heim (2010) "Jobs and Income Growth of Top Earners and the Causes of Changing Income Inequality: Evidence from U.S. Tax Return Data." available at web.williams.edu/Economics/wp/BakijaColeHeimJobsIncomeGrowthTopEarners.pdf.

Banning, Kevin and Ted Chiles (2007) "Trade-Offs in the Labor Union-CEO Compensation Relationship," Journal of Labor Research, Vol. 28, No. 2, pp. 347-357.

Barro, Robert J and Charles J Redlick (2011) "Macroeconomic effects from government purchases and taxes," The Quarterly Journal of Economics, Vol. 126, No. 1, pp. 51-102.

Bartels, Larry M (2009) Unequal democracy: The political economy of the new gilded age: Princeton University Press. 
Bebchuk, Lucian and Jesse Fried (2004) Pay without Performance: The Unfulfilled Promise of Executive Compensation: Harvard University Press.

Bertrand, Marianne and Antoinette Schoar (2003) "Managing with style: The effect of managers on firm policies," The Quarterly Journal of Economics, Vol. 118, No. 4, pp. 11691208.

Blackburn, McKinley L (2008) "Are union wage differentials in the United States falling?" Industrial Relations: A Journal of Economy and Society, Vol. 47, No. 3, pp. 390-418.

Blanchflower, David and Alex Bryson (2003) "Changes Over Time in Union Relative Wage Effects in the UK and the USA Revisited," International Handbook of Trade Unions, Cheltenham, UK: Edward Elgar Publishing Ltd, pp. 197-245.

Blanchflower, David G and Alex Bryson (2004) "What Effect Do Unions Have on Wages Now and Would Freeman and Medoff Be Surprised?" Journal of Labor Research, Vol. 25, No. 3.

Bloom, Nicholas, Benn Eifert, Aprajit Mahajan, David McKenzie, and John Roberts (2013) "Does Management Matter? Evidence From India," The Quarterly Journal of Economics, Vol. 128, No. 1, pp. 1-51.

Bluestone, Barry and Irving Bluestone (1992) Negotiating the Future: A Labor Perspective on American Business: BasicBooks.

Campolieti, Michele, Rafael Gomez, and Morley Gunderson (2013) "Managerial Hostility and Attitudes Towards Unions: A Canada-US Comparison," Journal of Labor Research, Vol. 34, No. 1, pp. 99-119.

Cowen, Tyler (2011) The Great Stagnation: How America Ate All The Low-Hanging Fruit of Modern History, Got Sick, and Will (Eventually) Feel Better: Dutton Adult.

Ebenstein, Avraham, Ann Harrison, Margaret McMillan, and Shannon Phillips (2013) "Estimating the impact of trade and offshoring on American workers using the current population surveys," Review of Economics and Statistics.

Feldstein, Martin (1995) "The Effect of Marginal Tax Rates on Taxable Income: A Study of the 1986 Tax Reform Act," Journal of Political Economy, Vol. 103, pp. 551-572.

Frank, Robert H and Philip J Cook (2010) The winner-take-all society: Why the few at the top get so much more than the rest of us: Random House.

Gabaix, Xavier and Augustin Landier (2008) "Why Has CEO Pay Increased so Much?" Quarterly Journal of Economics, Vol. 123, No. 1, pp. 49-100.

Goldin, Claudia Dale and Lawrence F Katz (2009) The race between education and technology: Harvard University Press. 
Gomez, Rafael, Morley Gunderson, and René Morissette (2013) "Labour adjustment implications of service offshoring: evidence from Canada," British Journal of Industrial Relations, Vol. 51, No. 1, pp. 148-173.

Gomez, Rafael and Konstantinos Tzioumis (2011) "What do Unions do to Executive Compensation?". available at papers.ssrn.com/sol3/papers.cfm, abstract id=1032796.

Hart, Oliver (1982) "A model of imperfect competition with Keynesian features," The Quarterly Journal of Economics, Vol. 97, No. 1, pp. 109-138.

Hirsch, Barry (2008) "Sluggish Institutions in a Dynamic World: Can Unions and Industrial Competition Coexist?" Journal of Economic Perspectives, Vol. 22, No. 1, pp. 153-176.

Hirsch, Barry T and David A Macpherson (2002) "Union membership and coverage database from the current population survey: Note," Indus. \& Lab. Rel. Rev., Vol. 56, p. 349.

Jones, Charles I (1995) "Time series tests of endogenous growth models," The Quarterly Journal of Economics, pp. 495-525.

Kaplan, Steven N (2012) "Executive compensation and corporate governance in the US: Perceptions, facts and challenges,'Technical report, National Bureau of Economic Research.

Kochan, Thomas A., Harry C. Katz, and Robert B. McKersie (1986) The Transformation of American Industrial Relations: Basic Books, Inc.

Lasselle, Laurence and Serge Svizzero (2005) Trends in Macroeconomics Research, Chap. On The Existence Of A Cournot Equilibrium With Endogenous Income, pp. 31-45: Nova Publishers.

Lemieux, Thomas (2008) "The changing nature of wage inequality," Journal of Population Economics, Vol. 21, No. 1, pp. 21-48.

Lipset, Seymour Martin, Noah M Meltz, Rafael Gomez, and Ivan Katchanovski (2005) The Paradox of American Unionism: Why Americans Like Unions More Than Canadians do but Join Much Less: Cornell.

Milligan, Kevin and Michael Smart (2015) "Taxation and top incomes in Canada," Canadian Journal of Economics, Vol. 48, No. 2, p. Forthcoming.

Moffitt, Robert A. and Mark O. Wilhelm (2000) Does Atlas Shrug?, Chap. Taxation and the Labor Supply Decisions of the Affluent, pp. 193-234: Russell Sage Foundation.

Mortensen, Dale T and Christopher A Pissarides (1994) "Job creation and job destruction in the theory of unemployment," The review of economic studies, Vol. 61, No. 3, pp. 397-415.

Olson, Mancur (1965) The logic of collective action: public goods and the theory of groups., Vol. 124: Harvard University Press. 
Piketty, Thomas, Emmanuel Saez, and Stefanie Stantcheva (2014) "Optimal Taxation of Top Labor Incomes: A Tale of Three Elasticities," American Economic Journal: Economic Policy, Vol. 6, No. 1, pp. 230-271.

Piketty, Thomas and Emmanuel Saez (2003) "Income Inequality in the United States, 19131998," Quarterly Journal of Economics, Vol. 118, No. 1, pp. 1-39.

Saez, Emmanuel, Joel Slemrod, and Seth H. Giertz (2012) "The Elasticity of Taxable Income with Respect to Marginal Tax Rates: A Critical Review," Journal of Economic Literature, Vol. 50, No. 1, pp. 3-50.

Slemrod, Joel B. (2000) Does Atlas Shrug?, Chap. The Economics of Taxing the Rich, pp. 3-28: Russell Sage Foundation.

Taber, Christopher R. (2000) Does Atlas Shrug?, Chap. Commentary on Chapter 7, pp. 235-239: Russell Sage Foundation.

Tosi, Henry L., Steve Werner, Jeffrey P. Katz, and Luis R. Gomez-Mejia (2000) "How Much Does Performance Matter? A Meta-Analysis of CEO Pay Studies," Journal of Management, Vol. 26, No. 2, pp. 301-339.

Walton, Richard E., Joel E. Cutcher-Gershenfeld, and Robert B. McKersie (1994) Strategic Negotiations: A Theory of Change in Labor-Management Relations: Harvard Business School Press.

\section{A Stationarity and Non-Stationarity in Long-Term Trend Data}

As noted in the text, Jones [1995] argues against using non-stationary explanatory variables to explain a stationary dependent variable such as growth in real GDP per capita ${ }^{11}$. Jones's argument is that if a variable is stationary it will return to its long-run trend. If the explanatory variables in the model are all trending up or down-for example, physical capital investment, human capital levels, or resources devoted to $R \& D$ - then the theory fails the empirical test. And there is little question that, using annual data, non-stationarity in real GDP per capita growth can be firmly rejected using the Dickey-Fuller or Phillips-Perron test. In fact, these tests reject non-stationarity in all of the growth variables in the model as

\footnotetext{
${ }^{11} \mathrm{My}$ thanks to an anonymous reviewer who raised these objections and suggested this line of reasoning.
} 
well as annual growth in average income for the top $1 \%$ and top $0.01 \%$. But in the pre-1974 range, the average annual income growth for these top two groups averaged $0.78 \%$ and $0.06 \%$ respectively. In the 1974-2008 time period, average annual growth increased to $3.14 \%$ for the top $1 \%$ and $6.34 \%$ for the top $0.01 \%$. Yet the MacKinnon approximate p-value on the Dickey-Fuller tests for these two variables is less than 0.00001, allowing us to confidently reject non-stationarity.

Table 3 presents the p-value of two unit root tests for the endogenous variables in the SEM regressions presented above, as well as for annual growth in average incomes for those at the top. There are significant differences between the annual data and the H-P trend. The tests are unable to reject non-stationarity for any of the H-P trend variables.

[Table 3 about here]

Figure 3 shows observed annual data and the calculated H-P trend for these growth variables. While the eye test says that the trend in real GDP per capita growth is perhaps the most likely to be stationary (at least after WWII), the others appear clearly not to be. Average income growth for the bottom $90 \%$ is clearly positive until the mid-1970s and then basically zero after that. Average income growth for both the top $1 \%$ and the top $0.01 \%$ has the opposite pattern in which it was close to zero or even negative until the mid-1970s and has been quite positive since then.

[Figure 3 about here.]

This suggests that the business cycle may be interfering in tests for stationarity. Because recessions are followed by expansions, and vice versa, the standard tests for stationarity may be setting themselves up for failure when looking for long-run changes in the trend. As we have seen, using the trend data calculated by applying the H-P filter, unit-root tests fail to reject the null-hypothesis of non-stationarity (Table 3). If this is the case, tests for cointegration should be used to check for a long-run relationship between the variables. 
Table 4 estimates the cointegrating rank of the structural equations in the model. There is significant evidence of cointegration between the variables in almost all of the structural equations.

\section{[Table 4 about here]}

This evidence of cointegration implies that a method such as fully-modified OLS (FMOLS) may be appropriate in identifying these long-run relationships. Table 5 presents FMOLS results for each of the structural equations (i)-(viii) while using the H-P trend data in the same way as Table 2. In addition, I present Dynamic OLS (DOLS) results using the (non-H-P trend) annual data. DOLS allows for a lead and lag of the explanatory variables. This is not dissimilar to taking the H-P trend which uses lags and leads to separate the cyclical effect from the long-run trend. Of course, the non-trend data, according to the unit-root tests in Table 3, are stationary, so this may not be an appropriate method. I also provide the direct effects from the SEM maximum-likelihood regressions in Table 2 for comparison.

\section{[Table 5 about here]}

The Fully Modified OLS regressions show very similar results to the Full Information Maximum Likelihood Structural Equation Model from section 3. The only significant exception is equation (iv) for imports as a percentage of GDP. Here, the signs switch for the top $0.01 \%$ and top $1 \%$ marginal tax rates (although none are very significant) and private union membership is strongly correlated with lower imports as would be expected from the model. The general story of how top marginal tax rates affects the bottom $90 \%$ average income growth is basically the same. Higher marginal tax rates on the top $0.01 \%$ are correlated with higher private union membership and faster GDP growth. Higher union membership, in this case, is associated with lower imports. And both higher growth and lower imports are associated with faster growth in average income for the bottom $90 \%$.

The Dynamic OLS regressions, which do not use the H-P trend data and include only one lag and one lead for the explanatory variables, show somewhat different results. This 
is especially true for the dependent variables which are now not $\mathrm{H}-\mathrm{P}$ filtered, the bottom 90\% average income growth (i) and real GDP per capita growth (ii). Looking at column (ii), this appears to be capturing business cycle effects which have been removed from the SEM FIML and FMOLS regressions with the H-P trend variables. The DOLS results are, not surprisingly, much more similar in the columns that do not include business cycle variables such as union membership (iii) and imports (iv).

These results still do not identify causation between the variables, but as they are generally consistent with the Full Information Maximum Likelihood Structural Equation Model from section 3, we can be more confident that issues of stationarity are not obscuring the true correlations between the variables of interest. 
Table 1: Summary Statistics, 1930-2008

\begin{tabular}{|c|c|c|c|c|c|c|c|c|}
\hline \multirow[b]{2}{*}{ Variable } & \multicolumn{4}{|c|}{$1930-2008$} & \multicolumn{2}{|c|}{$1948-1973$} & \multicolumn{2}{|c|}{$1974-2008$} \\
\hline & Mean & St. Dev. & Min & $\operatorname{Max}$ & Mean & St. Dev. & Mean & St. Dev. \\
\hline \multicolumn{9}{|c|}{ Endogenous Variables } \\
\hline Bottom $90 \%$ Average Income Growth* & 1.75 & 2.35 & -2.00 & 8.13 & 2.43 & 0.71 & 0.07 & 0.48 \\
\hline Real GDP Growth per capita* & 2.47 & 1.49 & 0.35 & 7.15 & 2.06 & 0.69 & 1.94 & 0.25 \\
\hline Top $0.01 \%$ Average Income Growth* & 2.25 & 4.22 & -3.99 & 11.24 & 0.06 & 1.07 & 6.34 & 2.60 \\
\hline Top 1\% Average Income Growth* & 1.79 & 1.86 & -2.54 & 5.86 & 0.93 & 0.82 & 3.14 & 1.66 \\
\hline Private Union Membership & 21.64 & 9.78 & 7.40 & 35.70 & 32.05 & 2.95 & 13.25 & 5.06 \\
\hline Imports/GDP & 7.49 & 4.22 & 2.84 & 17.89 & 4.55 & 0.70 & 11.72 & 2.63 \\
\hline Corporate Profits/GDP* & 9.01 & 1.72 & 4.62 & 11.00 & 10.46 & 0.61 & 8.65 & 0.90 \\
\hline Wages \& Salaries/GDP* & 49.50 & 2.08 & 45.19 & 51.66 & 51.45 & 0.18 & 47.43 & 1.34 \\
\hline Top $0.01 \%$ Marginal Fed Tax Rate & 59.49 & 20.31 & 24.0 & 92.0 & 76.75 & 7.76 & 45.67 & 14.68 \\
\hline Top 1\% Marginal Fed Tax Rate & 35.98 & 13.33 & 3.0 & 54.0 & 42.29 & 4.72 & 39.83 & 8.71 \\
\hline \multicolumn{9}{|c|}{ Exogenous Variables*** } \\
\hline Overall Average MTR** & 27.64 & 11.43 & 1.8 & 41.8 & 25.87 & 2.84 & 37.41 & 2.14 \\
\hline Total Federal Taxes/GDP & 15.47 & 4.67 & 3.28 & 20.35 & 16.85 & 1.28 & 17.88 & 1.01 \\
\hline Log Average Income & 10.37 & 0.43 & 9.47 & 10.87 & 10.37 & 0.19 & 10.72 & 0.09 \\
\hline Exports/GDP & 6.83 & 2.73 & 2.01 & 12.92 & 5.08 & 0.62 & 9.55 & 1.39 \\
\hline Percent Democrat House & 57.42 & 8.13 & 37.70 & 76.78 & 57.26 & 5.75 & 56.14 & 7.11 \\
\hline Percent Democrat Senate & 55.91 & 8.87 & 40.63 & 79.17 & 57.44 & 6.97 & 51.26 & 5.83 \\
\hline Democratic President & 0.51 & 0.50 & 0 & 1 & 0.50 & 0.51 & 0.34 & 0.48 \\
\hline
\end{tabular}




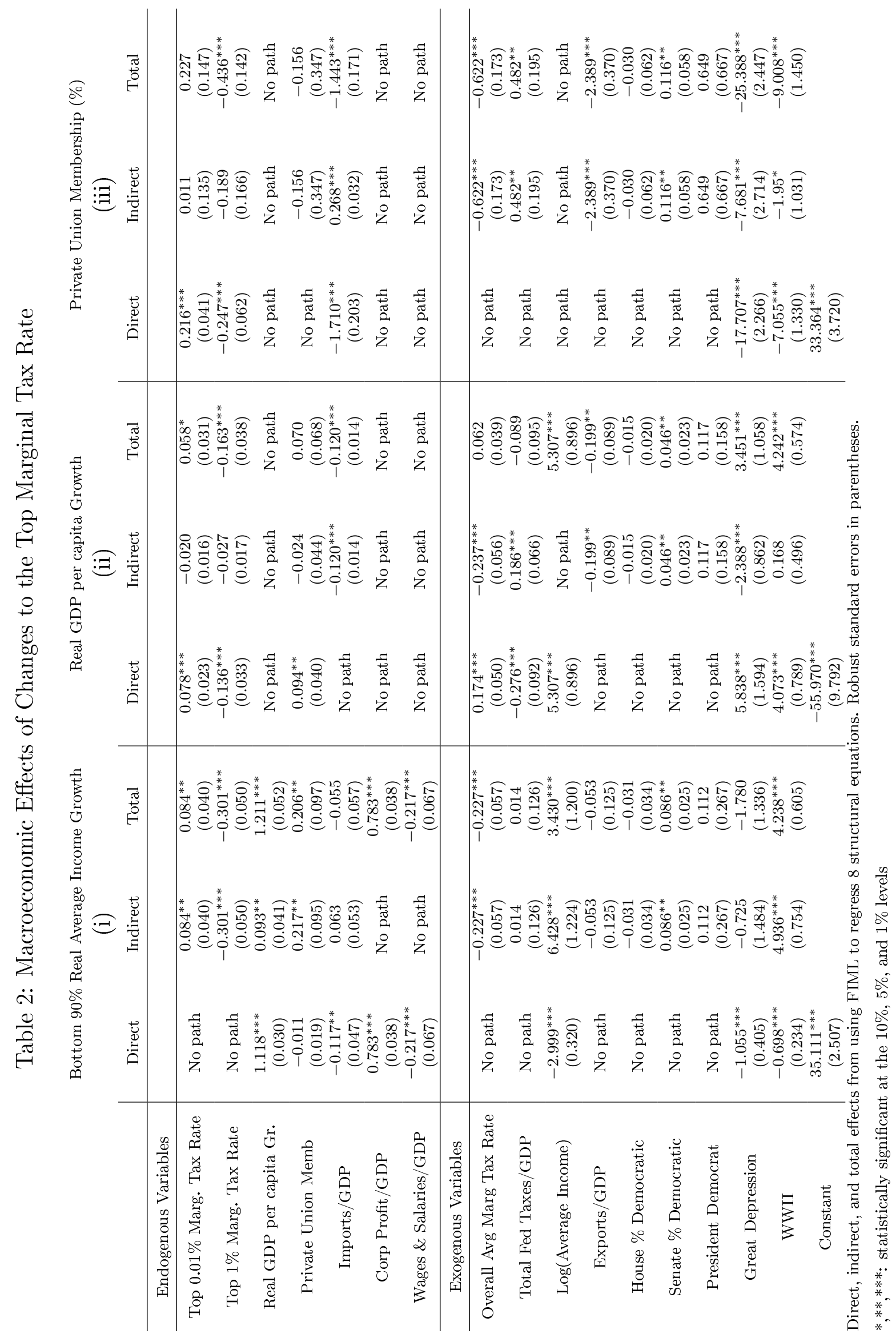




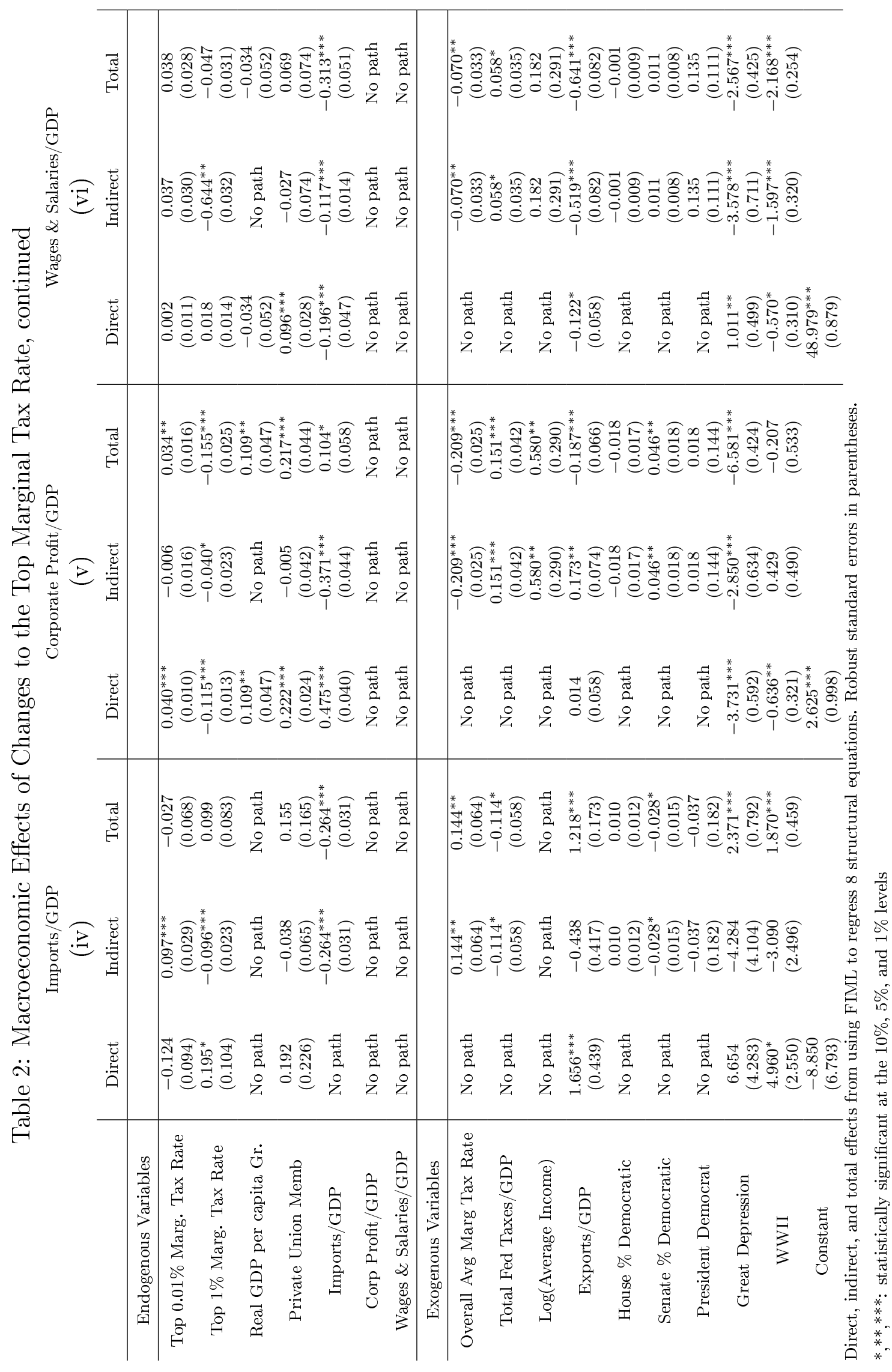




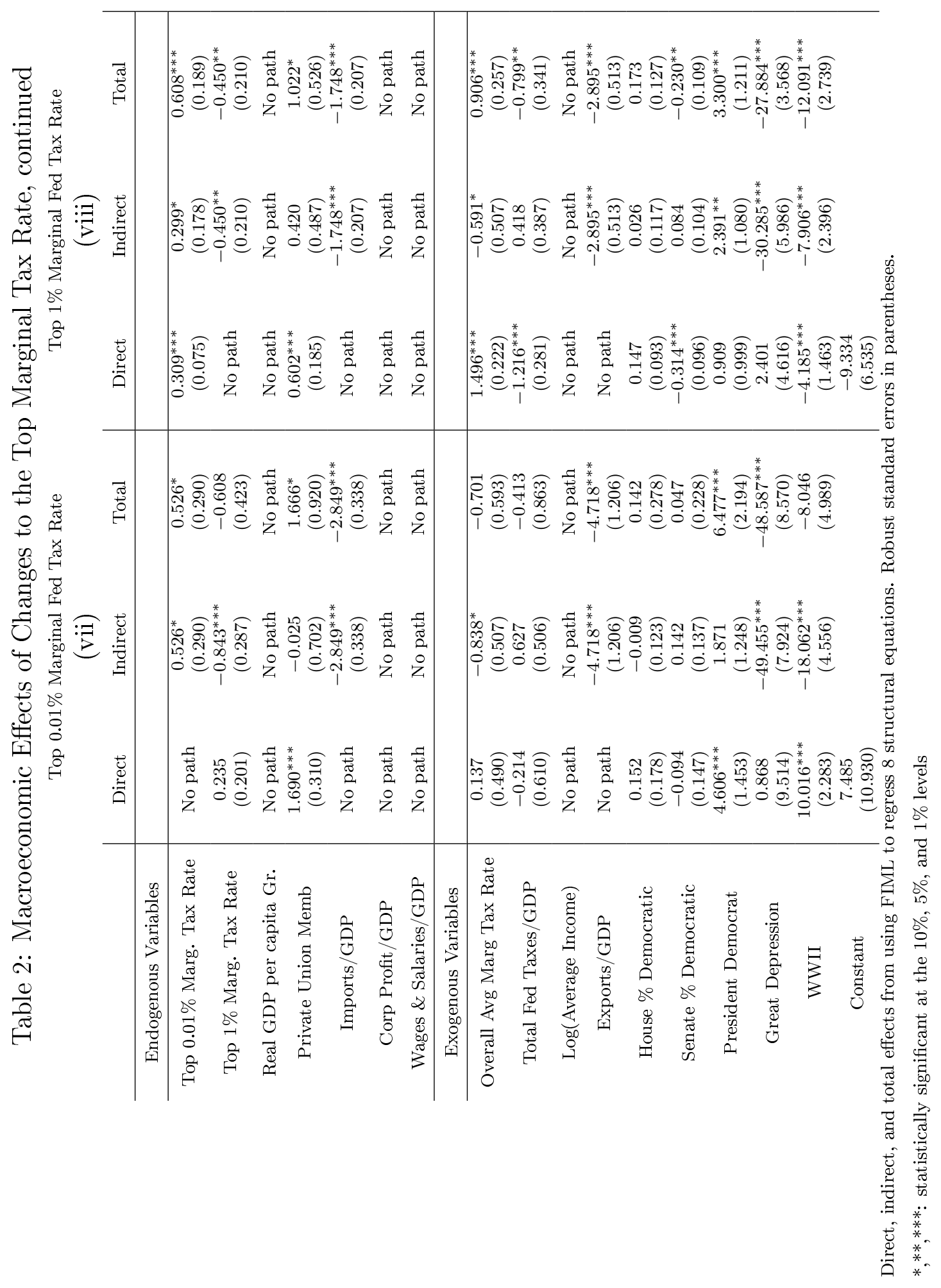


Table 3: Tests for stationarity in endogenous variables (business cycle vs. trend data)

\begin{tabular}{l|cc|cc} 
Variable & \multicolumn{2}{|c|}{ Dickey-Fuller (p-value) } & \multicolumn{2}{|c}{ Phillips-Perron** (p-value) } \\
& Annual Data & H-P Trend & Annual Data & H-P Trend \\
Bottom 90\% Avg. Inc. Gr. & 0.0001 & 0.6014 & 0.0000 & 0.3237 \\
Real GDP per Capita Gr. & 0.0000 & 0.5395 & 0.0000 & 0.1663 \\
Private Union Memb & 0.9674 & N/A & 0.9102 & N/A \\
Imports/GDP & 0.9989 & N/A & 0.9991 & N/A \\
Corp Profit/GDP & 0.1038 & 0.2939 & 0.0293 & 0.3587 \\
Wages \& Salaries/GDP & 0.7368 & 1.0000 & 0.6449 & 0.9974 \\
Top 0.01\% Marg. Tax Rate & 0.5547 & N/A & 0.4986 & N/A \\
Top 1\% Marg. Tax Rate & 0.1751 & N/A & 0.1732 & N/A \\
\hline Top 0.01\% Avg. Inc. Gr.* & 0.0000 & 0.8307 & 0.0000 & 0.7062 \\
Top 1\% Avg. Inc. Gr.* & 0.0000 & 0.3822 & 0.0000 & 0.2768
\end{tabular}

Table shows MacKinnon p-value for the Dickey-Fuller or Phillips-Perron test for unit root. All variables from 1930-2008.

* Variables not included in SEM in main results. Presented here for illustrative purposes.

** Includes 3 Newey-West lags 
Table 4: Cointegration rank of structural equations

\begin{tabular}{cccc} 
Equation & $\begin{array}{c}\text { Dependent } \\
\text { Variable }\end{array}$ & $\begin{array}{c}\text { Number of } \\
\text { Independent Variables* }\end{array}$ & $\begin{array}{c}\text { Cointegration Rank } \\
\text { (Johansen Test)** }\end{array}$ \\
\hline (i) & Bottom 90\% Real Average Income Growth & 6 & 5 \\
(ii) & Real GDP per capita Growth & 6 & 4 \\
(iii) & Private Union Membership (\%) & 3 & 0 \\
(iv) & Imports/GDP & 4 & 1 \\
(v) & Corporate Profit/GDP & 6 & 3 \\
(vi) & Wages \& Salaries/GDP & 6 & 3 \\
(vii) & Top 0.01\% Marginal Fed Tax Rate & 6 & 3 \\
(viii) & Top 1\% Marginal Fed Tax Rate & 6 & 3
\end{tabular}

* Excludes dummy variables for Great Depression, WWII, and Democratic President due to collinearity.

** Largest rank for which trace statistic is larger than the $5 \%$ critical value. Includes two lags. 


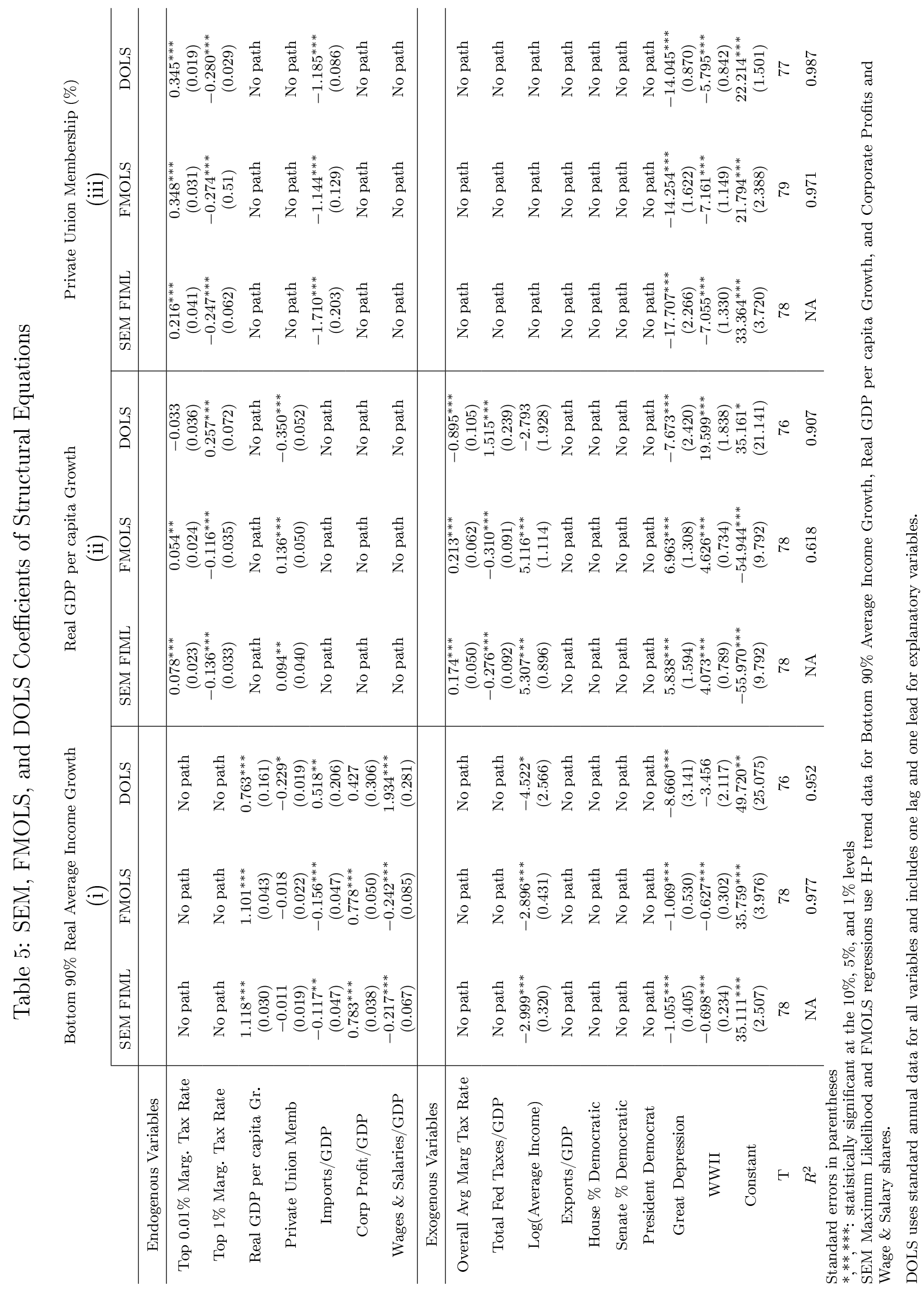




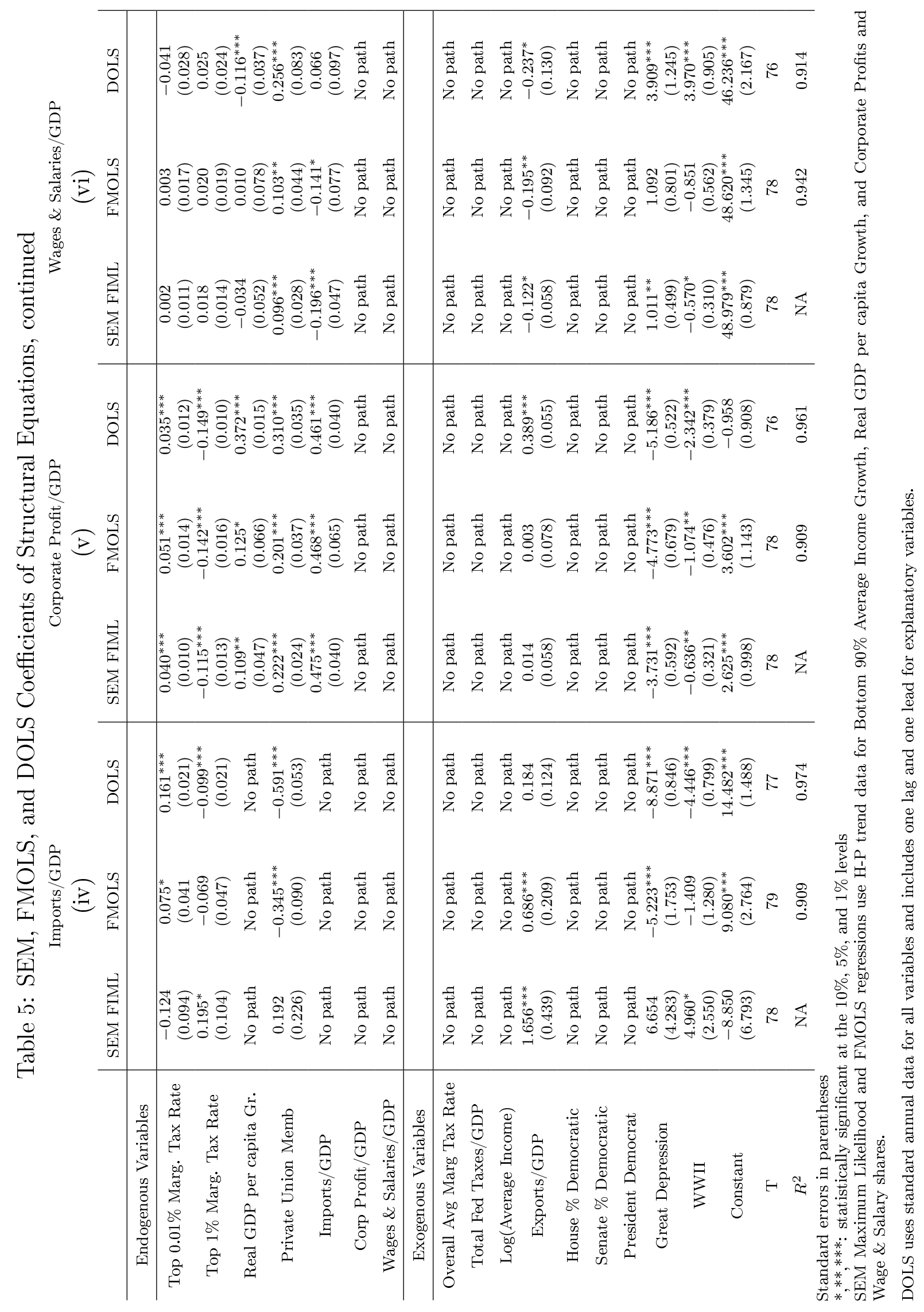




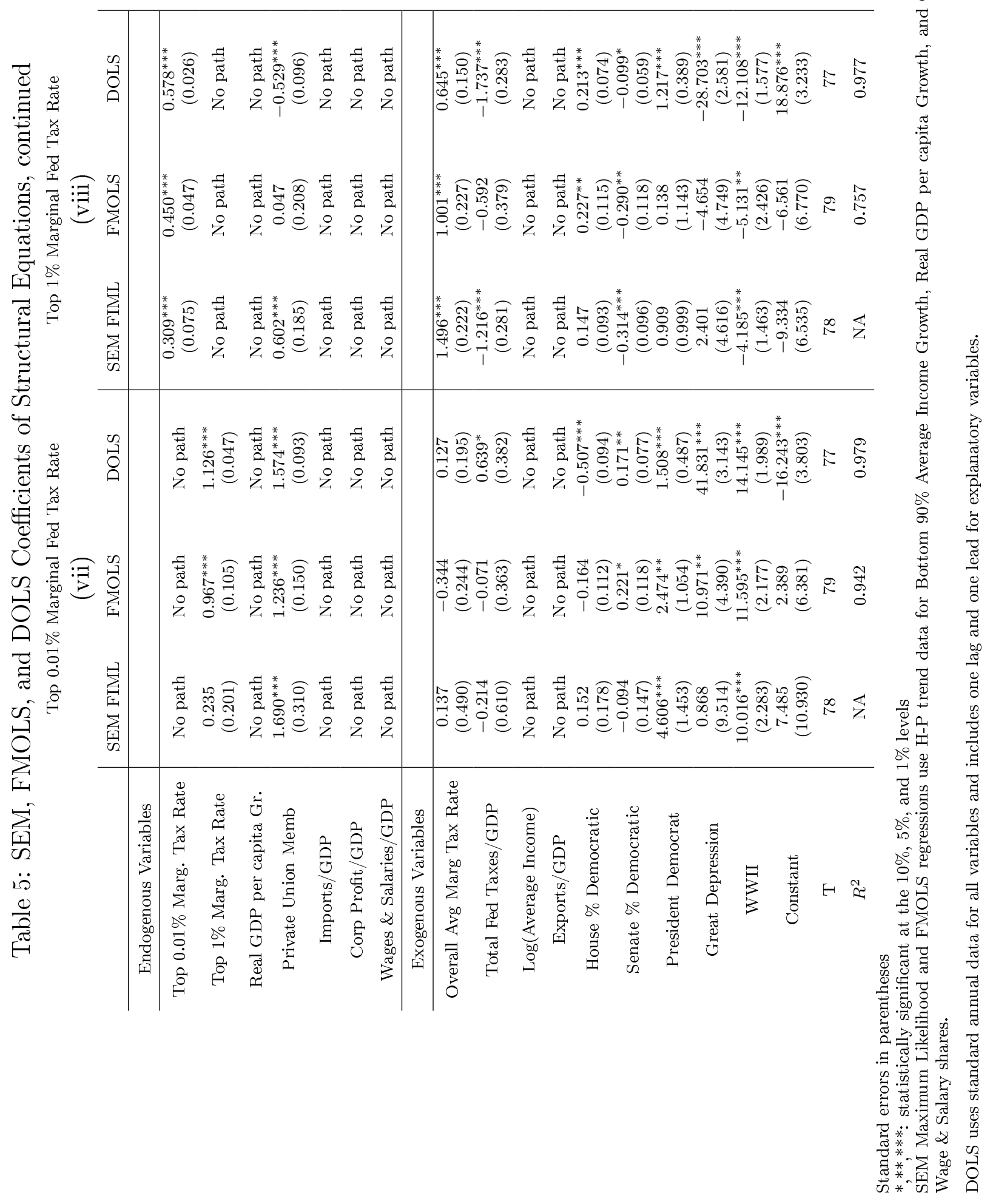


Figure 1: Marginal Tax Rates and Unionization

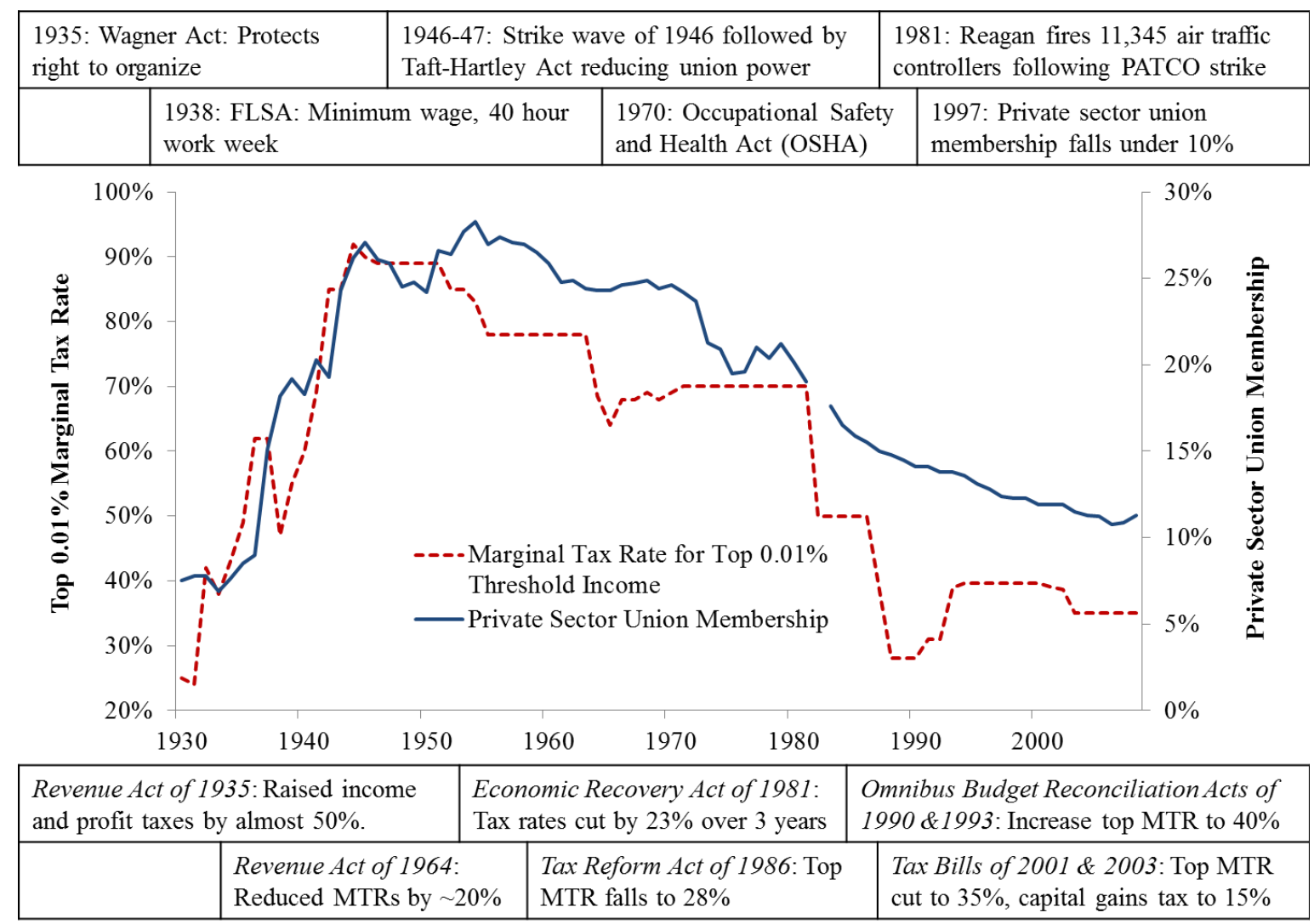


Figure 2: Path Analysis Diagram of Endogenous Variables

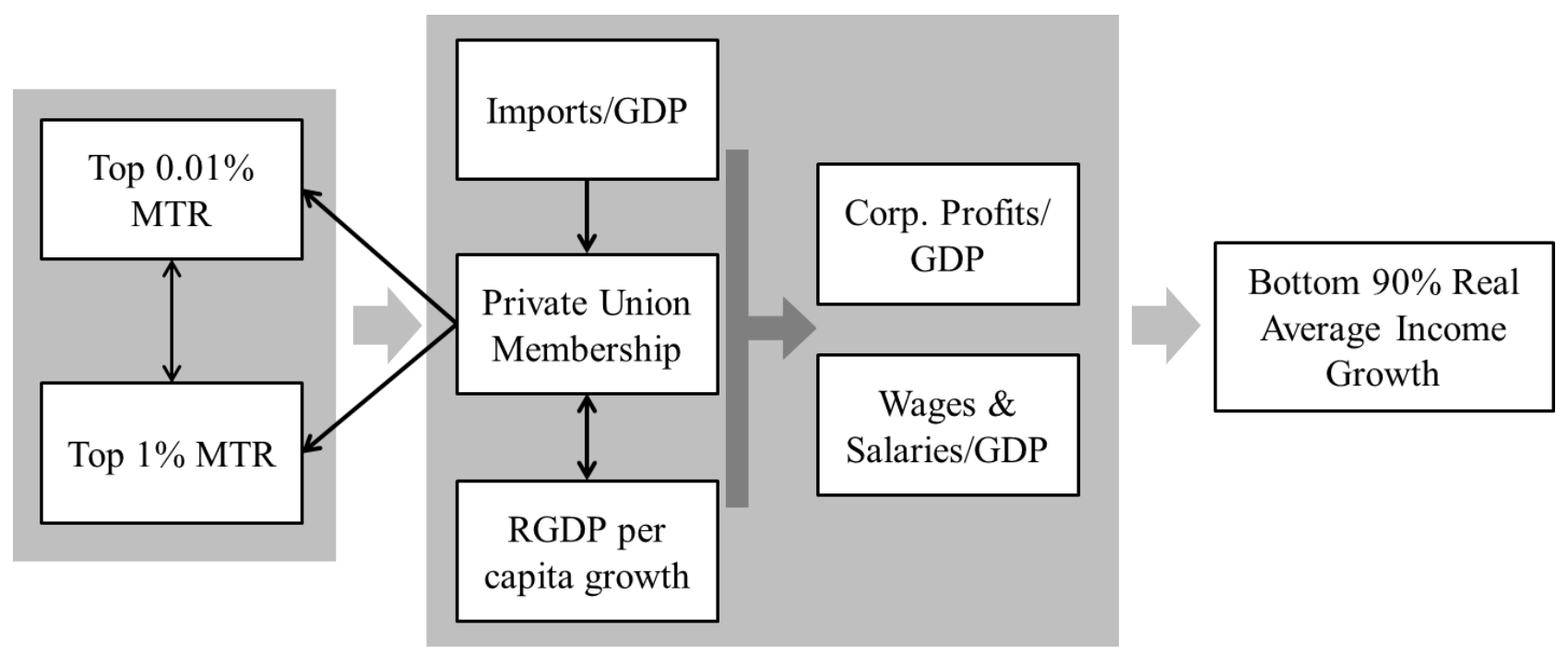

Exogenous Variables Excluded 
Figure 3: Annual data vs. H-P trend data, various growth rates
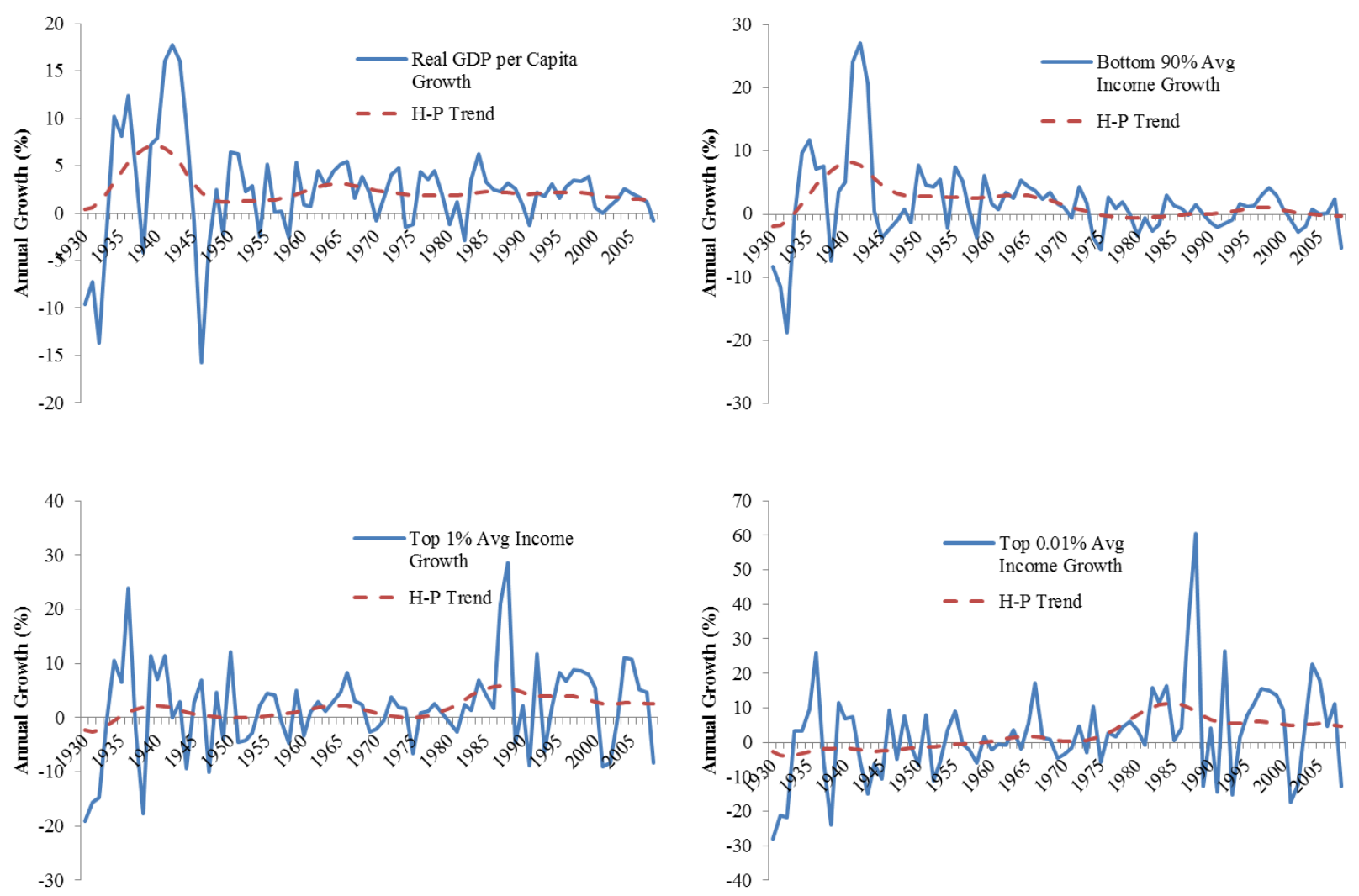